\title{
Non-cancellable Operating Leases and Operating Leverage
}

\author{
Figen Gunes Dogan
}

Faculty of Business Administration, Bilkent University, 06533 Ankara, Turkey

E-mail: figengunes@bilkent.edu.tr

\begin{abstract}
This paper explores the link between a firm's non-cancellable operating lease commitments and stock returns. Firms with more operating lease commitments earn a significant premium over firms with fewer commitments, and this premium is countercyclical. Non-cancellable operating lease payments represent a major claim on a firm's cash flows. Firms with high levels of operating leases have higher cash flow sensitivity to aggregate shocks and hence higher operating leverage. The relationship between operating leases and stock returns is stronger in small firms than in big firms.
\end{abstract}

Keywords: operating lease, operating leverage, cross section of expected returns

JEL classification: $E 22, G 12$

\section{Introduction}

Operating leases are the most common and important source of off-balance sheet financing, and operating lease use has increased substantially over the past several decades. ${ }^{1}$ According to Eisfeldt and Rampini (2009); leasing is of comparable

The author is grateful to Selale Tuzel for many comments and discussions. Furthermore, I would like to thank two anonymous referees and Kursat Aydogan, Cem Demiroglu, John Doukas (the Editor), Huseyin Gulen, Dong Lu, Armin Schwienbacher, and seminar participants at the 2014 PFMC Conference, the 2015 MFA conference, and Koc University for their helpful suggestions. Parts of this paper were written when the author was visiting the University of Southern California.

${ }^{1}$ Cornaggia et al. (2013) document that operating leases increased $745 \%$ as a proportion of total debt from 1980 to 2007. The Financial Accounting Standards Board (FASB) in the US and the International Accounting Standards Board (IASB) debated whether operating and capital leases should be combined and presented on the balance sheet (The Wall Street Journal, March 18 2014). The boards agreed to recognize certain operating leases on the balance sheet. However, they failed to reach a consensus on how to recognise expenses on the lessee's income statement. 
importance to long-term debt, and for small firms, leasing may be the largest source of external financing. ${ }^{2}$ These authors report that 'the proportion of capital that firms lease in merged Census-Compustat data is $16 \%$, which is similar to the long-term debt-to-assets ratio of $19 \%$.

Operating lease payments represent a major claim on firms' cash flows. Some of these leases are short term; they may be reversible and provide flexibility to the firm compared to ownership. However, some operating leases are non-cancellable during the lease term except in the event of bankruptcy. During the business cycle, firms cannot easily cancel or adjust the terms of this type of lease contract with their lessors. This inflexibility in operating lease costs increases firm risk. Firms with relatively high levels of operating lease commitment are more vulnerable to the business cycle than those with fewer commitments. Consequently, shareholders require a higher rate of return for bearing this risk, and expected stock returns of firms with higher levels of operating leases are greater compared to those of firms with lower levels of operating leases.

In this paper, I show that a firm's non-cancellable lease commitments are positively and monotonically related to expected returns. I construct a measure of the firm's operating lease ratio by dividing minimum lease commitments by the firm's total assets. This ratio represents the level of non-cancellable operating lease use. The sample includes US firms in the merged CRSP-Compustat database that report their lease commitments. On average, firms with high lease ratios have higher expected stock returns than firms with low lease ratios: a difference of $11.0 \%$ per annum for equalweighted portfolios and $4.7 \%$ per annum for value-weighted portfolios.

Firms with high levels of operating leases are riskier, especially during recessions. The return spread between high- and low-lease ratio firms is countercyclical and is about four times as high during recessions as it is during expansions. To investigate the risk mechanism behind expected returns, I show, first, that operating lease commitments have very limited comovement with sales. Second, the cash flows of firms with high levels of operating leases are more sensitive to aggregate shocks than those of firms with lower levels of operating leases. Third, I show that high-lease ratio firms have more volatile stock returns and cash flow growth.

The risks associated with holding non-cancellable operating leases are mentioned in the business press. For example, when UAL Corp., parent of United Airlines, filed for Chapter 11 in December 2002, it had US\$ 25.2 billion of assets, US\$22.2 billion of liabilities and US\$ 24.5 billion in non-cancellable operating lease commitments. A UAL spokeswoman acknowledges the company's high lease costs were a factor in UAL's bankruptcy. ${ }^{3}$ Similarly, US Airways filed for Chapter 11 in August 2002. Its chief executive officer, David Siegel, explained, ${ }^{4}$

\footnotetext{
${ }^{2}$ Graham et al. (1998) report that operating leases constitute $42 \%$ of fixed claims, whereas capital leases and debt are $6 \%$ and $52 \%$ of fixed claims, respectively, in the 1981-1992 Compustat data.

${ }^{3}$ Jonathan Weil, 'How Leases Play a Shadowy Role in Accounting', The Wall Street Journal, September 22, 2004.

4 'US Airways to Complete Restructuring Plan in Chapter 11 Reorganization', PRNewswire, August 12, 2002.
} 
'While US Airways was able to successfully negotiate cost savings from many of its employee groups, the company determined that it was unlikely to conclude consensual negotiations with certain vendors, aircraft lessors and financiers in a timeframe necessary to complete an out-of-court restructuring. Siegel cited as factors the large number of lessors and financiers and the company's inability to reject surplus aircraft leases and return excess aircraft outside of Chapter 11.'

The inflexibility of the firm's lease obligations creates cyclicality in the firm's cash flows, which is related to the concept of operating leverage. ${ }^{5}$ For shareholders, lease expense is a form of leverage that makes equity riskier. Danthine and Donaldson (2002) propose a general equilibrium model with labour-induced operating leverage. ${ }^{6}$ Their model with fixed labour costs generates operating leverage and provides a better match to the observed equity premium. Tuzel and Zhang (2013) show that firms have lower industry-adjusted average returns in areas where wages strongly comove with aggregate shocks. The idea of labour-induced operating leverage, that is, wages' limited comovement with revenues affecting firm risk, can be extended to operating leases. During recessions revenues fall but lease commitments do not fall by as much as revenues. These precommitted lease payments transfer the risk to shareholders. Therefore, in the setting of this paper, the operating leverage mechanism is created by the firm's non-cancellable leasing contracts.

The firm's financing and leasing decisions are possibly related. Debt and leases have been studied as both substitutes and complements. ${ }^{7}$ Chen et al. (2014) argue that firms with more inflexible operating costs endogenously choose lower financial leverage ex ante to reduce the likelihood of default in future bad states. Supporting the substitute argument, I find that firms that use higher levels of operating leases have lower financial leverage. To investigate whether a firm's financial leverage has an impact on the relationship between its operating leases and stock returns, I control for financial leverage in the Fama-Macbeth (1974) regressions and perform portfolio sorts with unlevered returns. Both results confirm that the lease premium is independent of financial leverage effects.

This paper makes the following contributions. A large body of literature on asset pricing links firm characteristics to stock returns in the cross-section. Fama and French (2008) provide a survey of this literature. To this literature, my paper adds the firm-level lease rate as a variable that constitutes part of a firm's operating leverage risk and establishes a link to expected stock returns.

Second, this paper contributes to the literature related to operating leverage. While the role of operating leverage on firm risk is studied in the theoretical works of Rubinstein (1973) and Lev (1974); there is limited supporting empirical evidence on the relationship between the firm's operating leverage and stock returns. The difficulty in measuring operating leverage is deciding on which costs are fixed, and on the degree and duration of the inflexibility of costs. Novy-Marx (2011) uses a measure of operating leverage - the

\footnotetext{
${ }^{5}$ See Lev (1974); Mandelker and Rhee (1984); Carlson et al. (2004) and Novy-Marx (2011). ${ }^{6}$ See Gourio (2007); Chen et al. (2011); Favilukis and Lin (2013) and Donangelo (2014) for examples of labour induced operating leverage studies.

${ }^{7}$ See Ang and Peterson (1984), Lewis and Schallheim (1992), Graham et al. (1998); Lasfer and Levis (1998) and Eisfeldt and Rampini (2009).
} 
firm's cost of goods sold plus selling, general, and administrative expenses, divided by the firm's total assets - and argues that firms with high operating leverage have higher expected returns. This measure includes a large set of costs, such as material and overhead costs or advertising and marketing expenses. The degree of the inflexibility of these costs is mixed. Some of these costs are more variable than fixed. Although noncancellable operating leases are only a component of a firm's inflexible commitments, they have a very high degree of inflexibility compared to other potential fixed costs. The firm discloses them as non-cancellable. Therefore, I can use the level of operating lease commitments as a direct measure of operating leverage. Examining the individual effect of operating leases is informative about the relationship between cash flow sensitivity, operating leverage risk and expected returns.

Third, this paper contributes to the cost stickiness literature in accounting ${ }^{8}$ and the wage stickiness literature in asset pricing. The literature related to cost stickiness studies adjustment costs, the magnitude of sales changes, expectations of future sales, and managerial empire-building behaviour as reasons for cost stickiness in the cross-section. The present paper adds contractual operating lease commitments as a reason for cost stickiness.

Finally, this paper contributes to the accounting literature that examines operating leases and equity risk. Imhoff et al. (1993), using 6 years of data, find that in the airline and grocery industries, debt-to-equity ratios, that are adjusted by capitalising operating leases are more highly correlated with the standard deviation of stock returns than those that are not so adjusted. Ely (1995) tests whether using operating lease-adjusted debt-to-equity and return-on-assets (ROA) ratios has more power in explaining the standard deviations of stock returns. The author's sample period is 9 years, with 202 firms. Ely finds a significant relationship between the standard deviation of monthly returns and the debt-equity adjustment for operating leases. However, she finds mixed results with adjustments made to ROA ratios. Dhaliwal et al. (2011) also find that the cost-of-equity-capital is positively associated with adjustments to financial leverage from capitalising off-balance sheet operating leases. The present study covers a longer period with a broader data set than previous studies, and investigates the direct relationship between operating leases-induced operating leverage and stock returns, rather than the relationship between financial leverage with capitalised operating leases and volatile stock returns or the cost-of-equity-capital.

In summary, this article shows that firms with high levels of non-cancellable operating lease commitments have more operating leverage, which amplifies exposure to business cycle risk, and consequently, these firms have higher expected stock returns. Section 2 examines the relationship between lease commitments and expected returns, sales, financial leverage, industry effects and cash flow sensitivity. Section 3 concludes the study.

\section{Empirical Analysis and Results}

This section demonstrates the empirical link between a firm's non-cancellable operating lease commitments and expected stock returns in the cross-section. A measure of the firm's level of operating leases relative to its total assets is constructed using widely

\footnotetext{
${ }^{8}$ See among others Anderson et al. (2003) and Chen et al. (2012).
} 
available accounting data. This ratio is called the operating lease ratio. I follow two complementary empirical methodologies to examine the relationship between the firm's operating lease ratio and its stock returns. In the first approach, I construct portfolios sorted on the lease ratio, and in the second approach, I run firm-level Fama-MacBeth regressions. These approaches allow a cross-check of the results and guide further testing to determine whether my operating lease variable is systematically related to firm risk.

\subsection{Data}

Statement of Financial Accounting Standards No. 13 requires firms to disclose future minimum rental payments for each of the five succeeding fiscal years and aggregate payments for years thereafter. For operating leases, Compustat has fields for 1-year through 5-year-out minimum operating lease commitments ( $M R C 1, M R C 2, M R C 3$, $M R C 4$, MRC5), 5-year total lease commitment (MRCT), commitments thereafter (beyond 5 years) (MRCTA), and rental expenses (XRENT). Short-term leases with a lease term of less than 1 year are reported under XRENT. MRCl is the minimum rental expense due in the first year under all existing non-cancellable operating leases. ${ }^{9}$ For year $t$, $M R C 1$ is reported at the end of year $t-1$ in a footnote to the balance sheet. Therefore, I use the minimum lease commitments due in year $1(M R C 1)$ lagged by 1 year as in Sharpe and Nguyen (1995) for the level of a firm's non-cancellable annual operating lease expense. This annual payment is divided by the firm's total assets. Using net property, plant, and equipment or the firm's total operating expenses instead of its total assets gives similar results.

Alternatively, I can estimate the present value of a firm's total non-cancellable operating lease commitments and use it instead of $M R C 1$ (an annual expense measure). There are three major approaches in the literature for estimating the stock value of operating leases. The first is the present value method. This approach capitalises the present value of minimum lease payments for 5 years $(M R C 1, M R C 2, M R C 3, M R C 4$, $M R C 5)$ plus the 'thereafter' value $(M R C T A)$ discounted at an appropriate discount rate. The second method is Moody's factor method, which capitalises operating leases by eight times the current-year rent expense. The third method of operating lease capitalisation, suggested by Lim et al. (2005), uses the perpetuity estimate of the operating lease payment. Lim et al. argue that the first method is known to significantly underestimate leased capital, since lease commitments are a lower bound on obligations and do not account for lease renewals; in addition, the availability of MRCTA is limited prior to 2000. The second and third methods either multiply or divide current-year operating lease expenses by a particular multiple or discount rate. Therefore, my measure of minimum operating lease commitments is a conservative measure of the noncancellable operating lease obligation and is free from assumptions about the discount rates used in the estimation and the firm's accounting practices with respect to operating leases. I also study only non-cancellable minimum rental commitments. However, some operating leases are cancellable but subject to termination penalties. This type of contractual obligation also contributes to the operating leverage effect.

\footnotetext{
${ }^{9}$ At the end of each year, the firm reports its future rental commitments. For example at the end of year $t, M R C 2$ is the minimum future lease payment due in year $t+2$.
} 
The key variable, the operating lease ratio, is as follows:

$$
\text { Operating Lease Ratio }=\frac{\text { Firm's operating lease payments }}{\text { Firm's total assets }}=\frac{M R C 1_{t-1}}{\text { Assets }_{t}} .
$$

I also track the following variables as control variables: Size is market capitalisation of the firm in June of the year $t+1$, from CRSP. Book-to-market ratio is measured for the fiscal year ending in calendar year $t .{ }^{10}$ I compare my lease ratio with Novy-Marx's (2011) operating leverage measure, which is the sum of the cost of goods sold plus selling, general and administrative expenses, divided by total assets. Financial leverage is the ratio of long-term debt plus debt in current liabilities, divided by total assets. As in Eisfeldt and Rampini (2009), I include cash and short-term investments to total assets ratio, and cash flow (income before extraordinary items plus depreciation and amortisation) divided by total assets to indicate firms that are financially constrained. I also compute the Kaplan and Zingales (1997) index, the Whited-Wu (2006) index and the Hadlock-Pierce (2010) size-age index as alternative financial constraint measures. ${ }^{11}$ Asset growth is change in the natural $\log$ of assets from year $t-1$ to year $t$, as in Cooper et al. (2008). Inventory growth is change in the natural log of total inventories, all measured from year $t-1$ to year $t$. The return on equity (ROE) is net income in year $t$ divided by book equity for year $t$. The return on assets (ROA) is net income in year $t$ divided by total assets for year $t$. The investment rate is capital expenditure minus sales of property, plant, and equipment at time $t$ divided by the average property, plant, and equipment at time $t-1$ and $t$, as in Belo et al. (2014).

The sample is an unbalanced panel with 4,926 distinct firms. Accounting data are from Compustat and span from 1975 to 2012. Monthly stock returns are from CRSP and from July 1976 to December 2013. My sample begins in 1975 since MRC1 is not available before 1975. Approximately $70 \%$ of firms in the Compustat population during this study's sample years report their minimum non-cancellable operating lease expense. I include only companies with ordinary shares and listed on NYSE, AMEX or NASDAQ. I exclude firms with missing Standard Industrial Classification (SIC) codes, negative book values, missing June market values, and missing or zero minimum lease commitments due in one year. As is standard, I omit regulated firms whose primary SIC code is between 4900 and 4999 (regulated firms) or between 6000 and 6999 (financial firms). I require firms to have a December fiscal-year end to align the accounting data

\footnotetext{
${ }^{10}$ Following Fama and French, I define book equity as stockholders equity, plus balance sheet deferred taxes and investment tax credit (if available), plus post-retirement benefit liabilities (if available), minus the book value of preferred stock. Depending on availability, I use redemption, liquidation, or par value (in that order) for the book value of preferred stock. If stockholder equity is not available, I use the book value of common equity plus the book value of preferred stock. If common equity is not available, I compute stockholder equity as book value of assets minus total liabilities.

${ }^{11}$ The five-variable Kaplan-Zingales index is constructed following Lamont et al. (2001). The size-age index is calculated as $\left(-0.737^{*}\right.$ Size $)+\left(0.043^{*}\right.$ Size 2$)-\left(0.040^{*}\right.$ Age $)$, where Size equals the log of inflation-adjusted book assets and Age is the number of years the firm is listed with a non-missing stock price in Compustat. Size is winsorized (i.e., capped) at (the log of) US\$ 4.5 billion and Age is winsorized at 37 years.
} 
across firms. In other words, my sample includes firms with a fiscal year ending only in December to ensure that the accounting data are not outdated by the time of the sorting procedure. However, my results are very similar if I drop this December fiscal year-end restriction (see section 2.11). Following Fama and French (1993), I include only firms with at least 2 years of data in the sample. The data for the five Fama-French (2014) factors - small-minus-big, SMB; high-minus-low, HML; market, MKT; robust-minusweak, RMW; and conservative-minus-aggressive, CMA - are from Kenneth French's web page.

\subsection{Portfolio sorts}

I construct 10 one-way-sorted lease portfolios and investigate the characteristics of these portfolios' post-formation average stock returns. Following Fama and French (1993), I match CRSP stock return data from July of year $t+1$ to June of year $t+2$ with lease ratio information for the fiscal year ending in year $t$, allowing for a minimum of a 6-month gap between the fiscal year-end and return tests. At the end of each June in year $t+1$, I sort the firms in the sample according to their lease ratio and group them into decile portfolios.

Table 1 below shows the dispersion in the descriptive characteristics of the lease ratiosorted portfolios, and Table 2 shows the time-series averages of the cross-sectional Spearman rank correlations among other firm characteristics. The first row in Table 1 provides data on the average level of the lease ratio of the firms in these decile portfolios. The results in Table 1 indicate a monotonic relationship between the lease ratio and size. Firms that have large non-cancellable lease obligations are small, with low financial leverage. These firms carry higher cash levels to fund lease payments and are financially constrained, as similarly measured in Eisfeldt and Rampini (2009) and Cosci et al. (2013). The profitability measure, ROA, which is also highly correlated to Eisfeldt and Rampini's internal available funds measure (cash flow), is monotonically and negatively related to operating lease commitments. The relationship with the other measure of profitability, ROE, and the operating lease ratio is not monotonic. Asset growth and inventory growth, both decrease monotonically with operating leases. The high correlation between firm size and the lease ratio is expected, as documented in Eisfeldt and Rampini (2009). The high positive correlation between Novy-Marx's (2011) operating leverage and my lease ratio is due to the similarity in the numerator. A firm's operating lease payments constitute a portion of the selling, general and administrative expenses. Despite the correlation, I show that my lease ratio has a significant impact after controlling for Novy-Marx's measure of operating leverage in Fama-MacBeth regressions.

One reason why firms lease their capital versus owning is given by Eisfeldt and Rampini (2009), who argue that although leasing is more costly due to the agency problem induced by the separation of ownership and control, financially constrained firms prefer leasing due to the benefit of higher debt capacity. Therefore, more financially constrained firms, which have limited internal funds, lease a larger proportion of their capital than less constrained firms do. The authors use the ratio of cash flow-to-assets as the most direct measure of available internal funds. In Table 1, cash flows-to-assets is negatively correlated with the proportion of leased capital. Firms with high lease commitments have lower cash flow-to-asset ratios and higher Kaplan and Zingales index values. The other measure of available funds, the cash-to-assets ratio, is positively correlated to my lease ratio. This cash measure, as explained by Eisfeldt and Rampini 


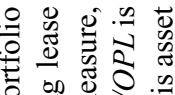

蔫

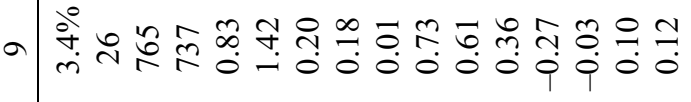

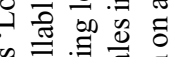

跣

त्र

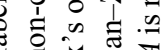

虽

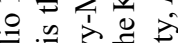

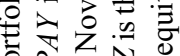

次武

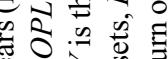

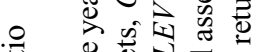

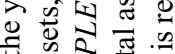

就过

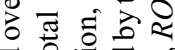

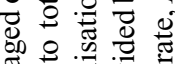

的㱐 $:$

起 :

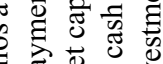

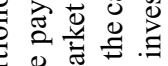

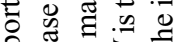

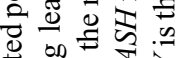

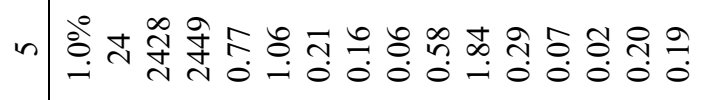

记泡之

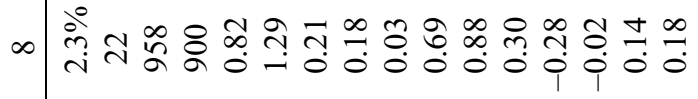

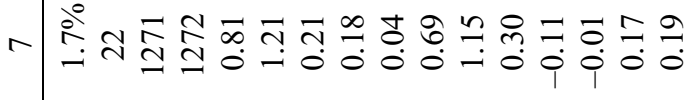

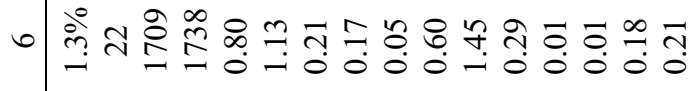

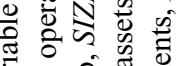

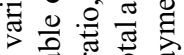

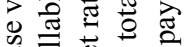

ब्ष

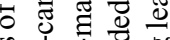

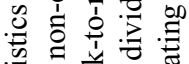

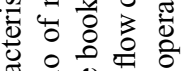

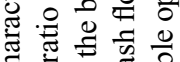

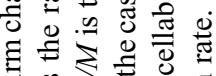

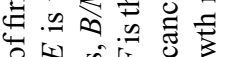

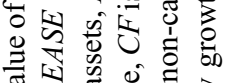

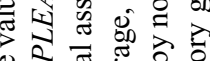

$\mathrm{S}_{\infty}$ 至

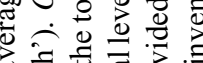

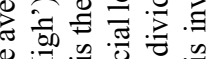

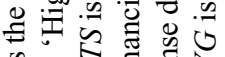

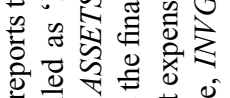

证

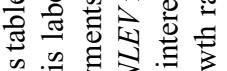

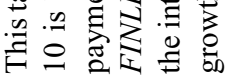

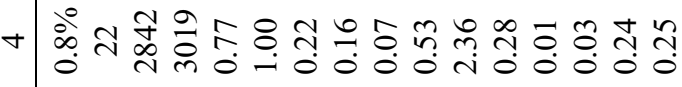

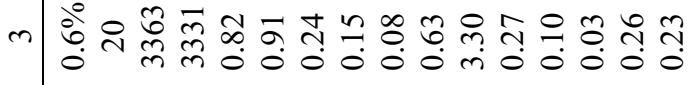

N|部

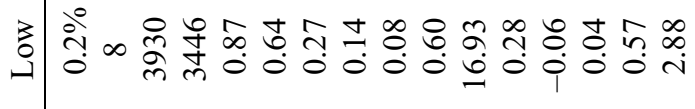

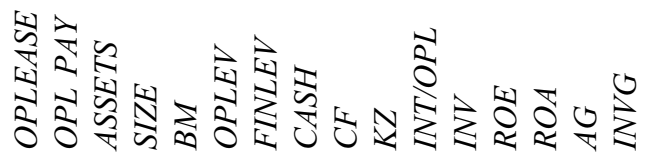




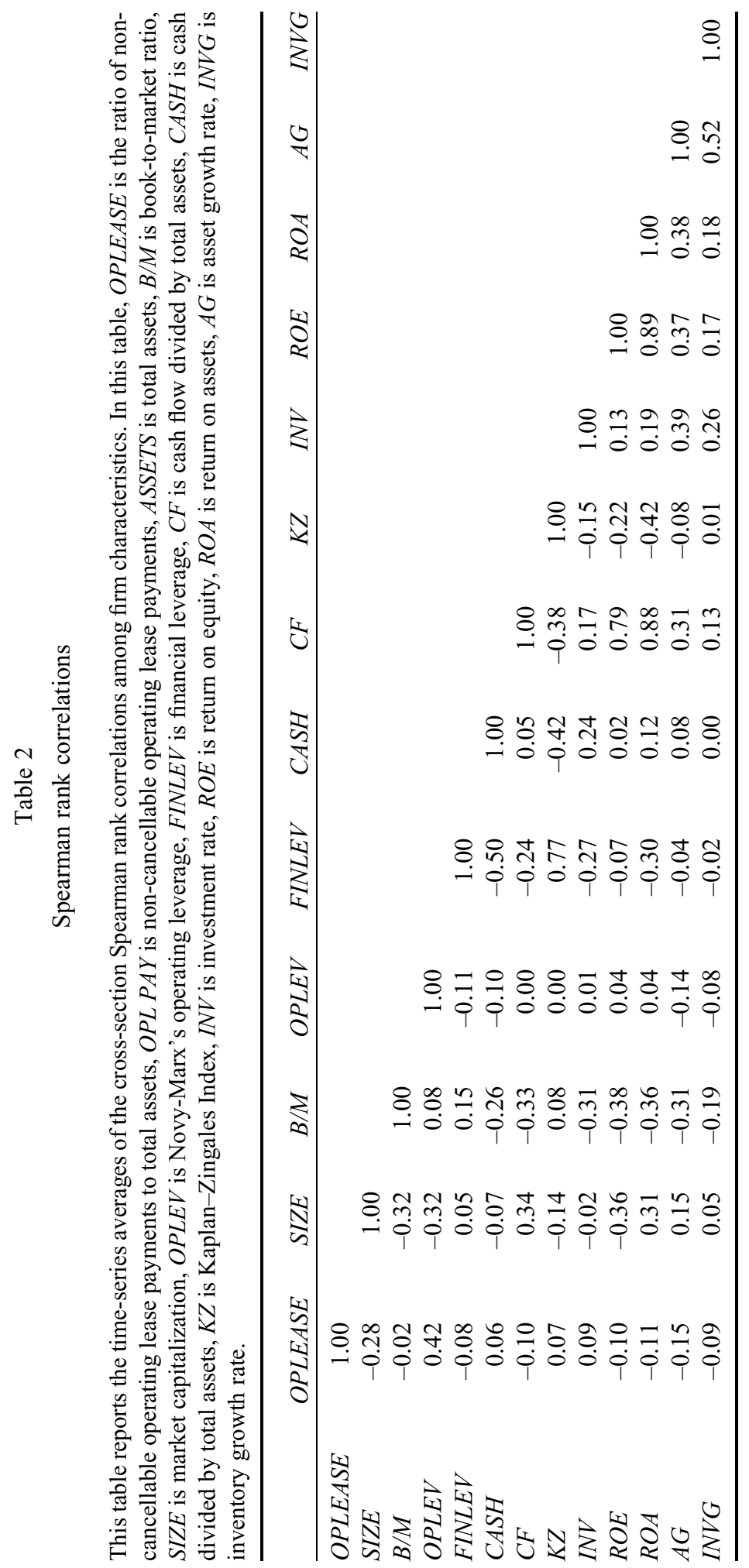


(2009), represents net working capital to fund firm operations. Therefore, firms with higher lease ratios have higher cash balances to compensate for their inflexible higher lease costs. However, their retained earnings are lower to finance capital investments. The fraction of interest expense to non-cancellable operating leases is also decreasing with the lease ratio. For firms in the higher lease ratio deciles, lease payments exceed interest expense.

\subsection{Returns of lease ratio sorted portfolios}

Table 3 investigates the relationship between my lease ratio and expected excess returns (excess of the risk-free rate). Ex-post realised stock returns are used as a proxy for expected returns. The table shows the dispersion in both equal and value-weighted portfolio returns for firms sorted into 10 portfolios based on the lease ratio. Expected returns of the portfolios increase monotonically with the lease ratio. The annualised difference between the returns of high- and low-lease ratio firms is $11.0 \%$ for equalweighted portfolios and $4.7 \%$ for value-weighted portfolios, both spreads being statistically significant.

To understand the relationship between the lease ratio and expected returns over business cycles, I separate my sample into expansionary and contractionary periods around the portfolio formation period (see Imrohoroglu and Tuzel, 2014 for a similar approach). I use (National Bureau of Economic Research) NBER business cycle dates as reported on the NBER website. I designate recession/expansion in June of each year and examine the returns of lease ratio-sorted portfolios over the succeeding 12 months.

I find that the positive relationship between the lease ratio and expected returns persists in both expansions and in contractions for equal-weighted portfolios. However, there are significant differences in returns over business cycles. The average level of expected returns is much higher in recessions than in expansions. The annualised spread between the returns of high and low lease ratio portfolios is also much higher during contractions, $29.0 \%$, than during expansions, $7.2 \%$, in equal-weighted portfolios. For value-weighted portfolios, the spread is $20.3 \%$ and is significant during contractions. However, the value-weighted spread is not significant during expansions.

Low-lease ratio firms have lower expected returns in recessions and high-lease ratio firms have lower expected returns during expansions compared to their average returns during all states. The increase in expected returns of high-lease portfolios is particularly large, from $18.1 \%$ in expansions to $37.8 \%$ in contractions. For low lease ratio firms, expected returns decrease from $10.9 \%$ in expansions to $8.8 \%$ in contractions in equalweighted portfolios, and they decrease from $7.5 \%$ to $-1.2 \%$ in value-weighted portfolios. A simple two-sample $t$-test with unequal variances confirms that the return spread in expansions is statistically different than in recessions. The $t$-statistics are -3.84 for the equal-weighted spread portfolio and -2.53 for the value-weighted spread portfolio. My interpretation of the spread in expected returns across these portfolios, especially in recessions, centres around the risk premia associated with the higher risk of high-lease ratio firms.

\subsection{Firm-level Fama-MacBeth regressions}

Portfolio sorts indicate a statistically and economically significant positive relationship between the lease ratio and returns. I now use a different approach to investigate the 


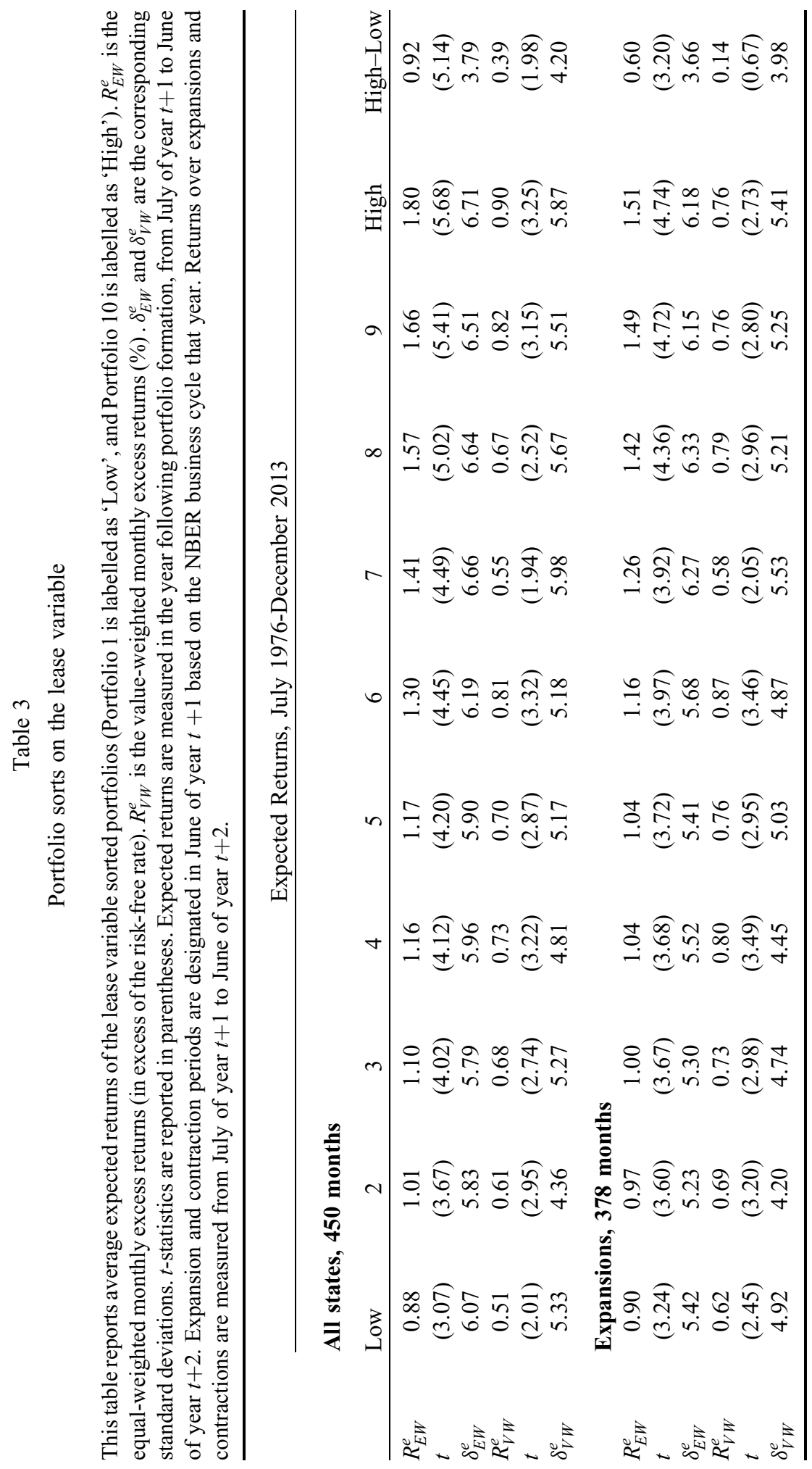




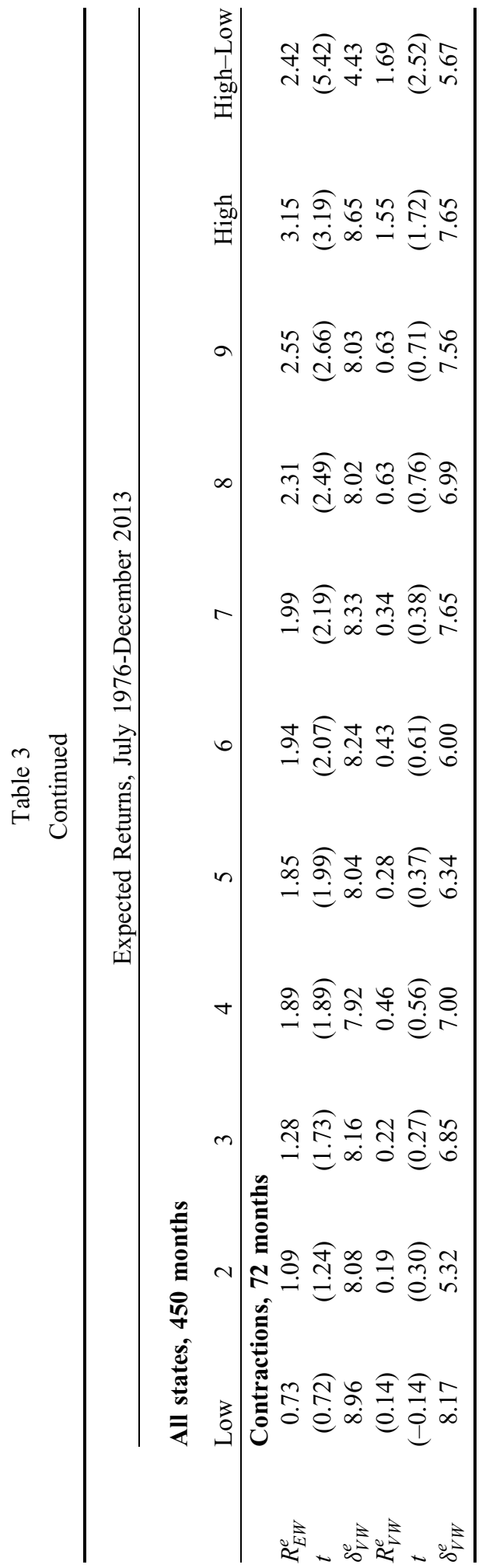


strength of the relationship between lease rates and stock returns. I run firm-level Fama-MacBeth cross-sectional regressions (Fama and MacBeth, 1973) to predict stock returns using the lagged firm-level lease rates as return predictors.

I estimate the following cross-sectional regression for firm $i=1, \ldots, N$ in each month:

$$
R_{i}=\propto+\beta \lambda_{i}+\gamma D_{i}+\varepsilon_{i}
$$

where, $i$ is a firm index, and monthly returns are denoted by $R_{i}$. My measure of the lease ratio is denoted by $\lambda_{i}$ and $D_{i}$ is a vector of controls. I measure $\lambda_{i}$ and all control variables based on accounting ratios at the end of the preceding year. I run the cross-sectional regression for each month separately. I then take the time series of the estimated monthly cross-sectional regression coefficients and calculate the mean regression coefficients. To test their significance, I report autocorrelation and heteroskedasticity corrected Newey and West (1987) standard errors for the estimated coefficients. The average regression coefficients are reported in Table 4.

I find that the lease rate is strongly positively related to expected returns. The crosssectional regression, in which the lease rate is the only explanatory variable, produces an average slope of 15.98. The magnitude of the effect is significant both statistically and economically. The 15.98 average regression coefficient translates into approximately $6.8 \%$ higher expected returns for firms in the highest lease decile compared to firms in the lowest lease decile. When I divide my sample into two time periods, the results are not sensitive to the sample period, although the effect is stronger in the first half of the sample period, fiscal years 1975 to 1993 .

To understand the marginal predictive power of the lease rate, I control for several firm characteristics that could be related to my lease ratio variable. As in Fama and French (2008), I do not include market beta, since the market beta for individual stocks is not precisely measured in the data. I find that the cross-sectional regressions that include the log size, log book-to-market, momentum, and operating leverage all produce positive and statistically significant average slopes for the lease ratio.

In the literature, empirical evidence on the relationship between financial leverage and stock returns is mixed. When other firm characteristics are included in regressions, financial leverage often becomes insignificant in predicting returns (Fama and French, 1992). ${ }^{12}$ The firm's financial leverage does not impact the relationship between its operating leases and stock returns.

Eisfeldt and Rampini (2009) argue that more financially constrained firms lease more of their capital than less constrained firms do. My results could be driven by financial constraints rather than the operating leverage effect. Therefore I control for four different measures of financial constraints, cash flow scaled by assets, the Kaplan and Zingales (1997) index, the size-age index of Hadlock and Pierce (2010) and the Whited-Wu (2006) index. $^{13}$ After controlling for these measures of financial constraints, the relationship between operating leases and returns remains. Cash flow scaled by assets ratio has a high correlation with ROA (0.88) and size-age (SA) index has a high correlation with size (0.84). Among those four measures, Hadlock and Pierce's size-age

\footnotetext{
${ }^{12}$ George and Hwang (2010) provide further evidence that the book leverage premium is weak and potentially negative.

${ }^{13}$ The six-variable Whited-Wu index is constructed following Whited and $\mathrm{Wu}$ (2006).
} 


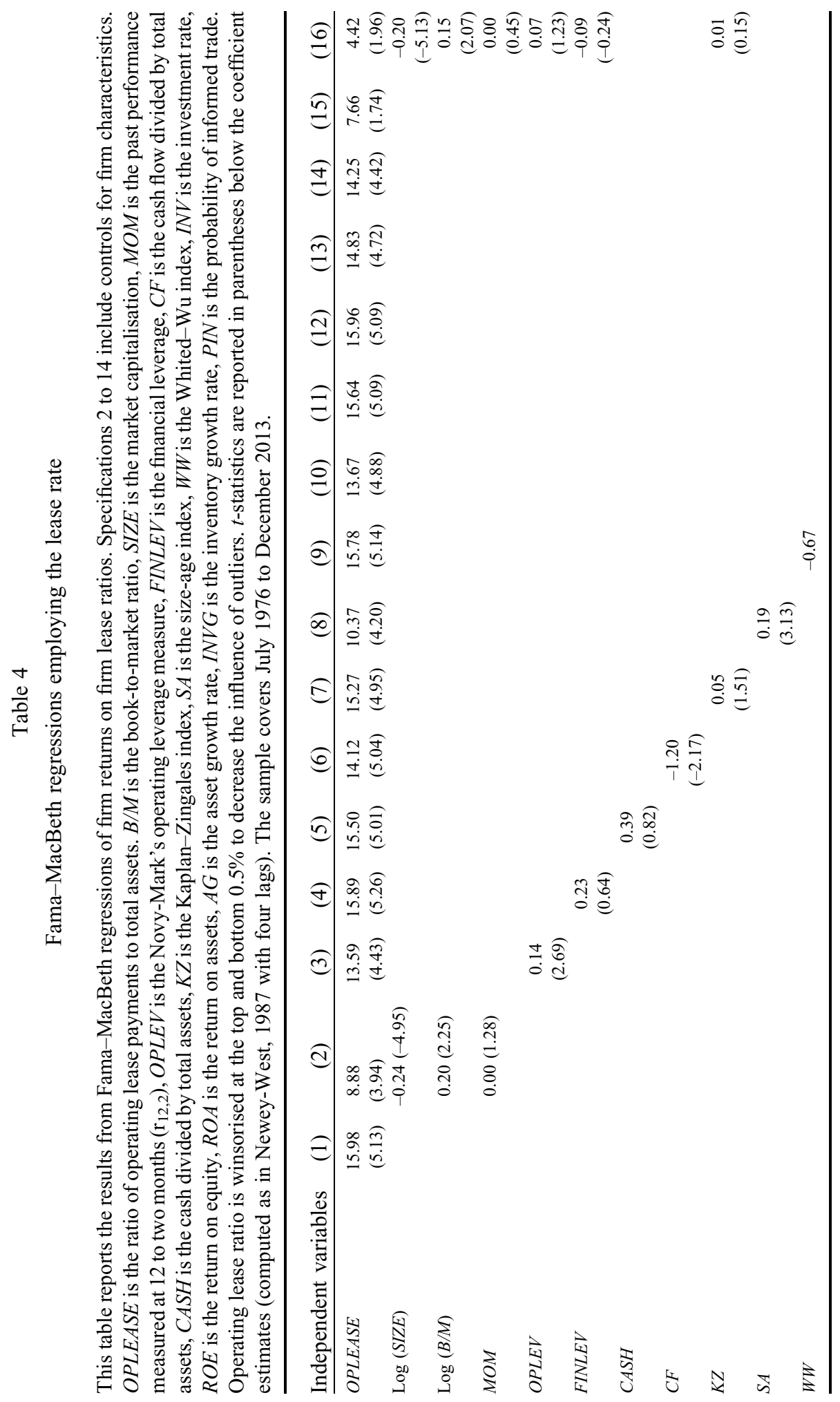




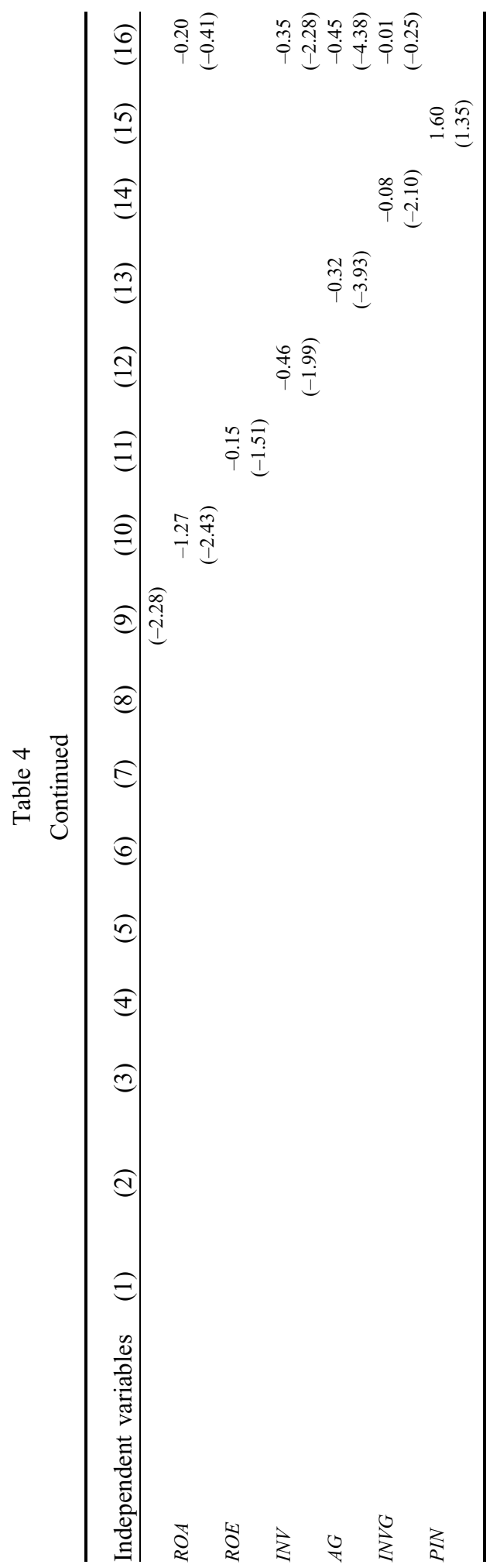


index is the most powerful and these financial constraint measures confirm the relationship that greater financial constraint leads to higher stock returns. When I include other control variables and financial constraint measures all together in the Fama-MacBeth regressions, the choice of financial constraint measure does not have an impact on the significance of the lease ratio.

The empirical evidence shows that the firm's capital investment is inversely related to expected returns. ${ }^{14}$ In Table 1 , firms with high lease ratios have lower asset and inventory growth rates. However, the correlation between the firm's investment rate and lease ratio is positive. In the cross-sectional regressions, when I control for these investment-related variables, the operating lease ratio's coefficient remains significant and positive. These findings show that the operating lease effect is not due to investment and profitability relationships.

I also control for the effects of possible information assymmetries created by the nature of operating lease transactions. Operating leases are typically found in the footnotes of financial statements and may not be properly reported. This accounting deficiency causes information risk. Probability of informed trade (PIN) is used as a measure of information risk in the literature (e.g., Easley et al., 2002). The PIN estimates span the period 1983-2001. ${ }^{15}$ Although the coefficient of the lease ratio is lower when the PIN measure is included in the regressions, it remains positive and statistically significant.

In the literature, taxes are widely seen as one of the most important reasons to lease. According to Lasfer and Levis (1998), "while large companies lease mainly for tax savings, small companies lease to overcome their inability to access debt to finance growth opportunities and survival.' Lewis and Schallheim's (1992) model implies that those firms with lesser ability to use tax shields are those for which leasing is most advantageous. I find that firms with high lease ratios have lower marginal tax rates. ${ }^{16}$ Although the question of why firms use leases is not the focus of this paper, taxes may have a mechanical link to firm risk. When I control for marginal tax rates in my regressions, operating leases have a coefficient of 6.24 , which is statistically significant at the $1 \%$ level.

Following Fama and French (2008), Table 5 presents the cross-sectional regression results for three groups of stocks - microcap, small, and big stocks - estimated separately. The three groups are classified using the Fama and French (2008) size breakpoints of the smallest $20 \%$, the middle $20 \%$ to $50 \%$, and the largest $50 \%$ of all NYSE firms. After controlling for size, book-to-market, and momentum, I observe that the relationship between operating leases and expected returns is stronger in smaller stocks than in bigger stocks. Gomes and Schmid (2010) explain that the relationship between financial leverage and stock returns is inconclusive because of the changing firm risk over the firm's lifecycle. In their investment-based asset pricing model, mature, bigger firms have greater financial leverage with low underlying asset risk, while small firms are more subject to operating leverage. Fixed costs of default are more important

\footnotetext{
${ }^{14}$ See for example, Cochrane (1991), Titman et al. (2004), and Cooper et al. (2008).

${ }^{15}$ PIN estimates are from Soeren Hvidkjaer's web site. Only NYSE and AMEX listed firms have PIN measures in this sample.

${ }^{16}$ Marginal tax rate estimates of Blouin et al. (2010) are used. The data are available from 1980.
} 
Table 5

Fama-MacBeth regressions employing the lease rate across different size groups

This table reports the results from Fama-MacBeth regressions of firm returns on firm lease ratios. Firms are assigned to size groups at the end of June each year. Microcap stocks (micro) are below the 20th percentile of the NYSE market cap at the end of June, small stocks are between the 20th and 50th percentiles, and big stocks are above the NYSE median. All but micro combines small and big stocks. OPLEASE is the ratio of operating lease payments to total assets. $B / M$ is the book-to-market ratio, SIZE is the market capitalization, $M O M$ is the past performance measured at 12 to 2 months. $t$-statistics are reported in parentheses next to the coefficient estimates, computed as in Newey-West (1987) with four lags. The sample covers July 1976 to December 2013.

\begin{tabular}{lcccc}
\hline & Micro-cap & Small-cap & Big-cap & All but micro \\
\hline OPLEASE & $6.27(2.86)$ & $5.48(1.57)$ & $7.19(1.65)$ & $5.97(1.78)$ \\
$\log ($ SIZE $)$ & $-0.63(-6.82)$ & $-0.05(-0.55)$ & $-0.07(-1.41)$ & $-0.10(-2.15)$ \\
$\log (B / M)$ & $0.10(1.01)$ & $0.21(2.08)$ & $0.18(1.95)$ & $0.19(2.13)$ \\
MOM & $0.00(1.61)$ & $0.00(1.59)$ & $0.00(1.23)$ & $0.00(1.35)$ \\
\hline
\end{tabular}

for small firms. Cross-sectional regressions excluding microcaps and including control variables also produce significant coefficients for the lease ratio.

\subsection{Asset pricing tests}

To investigate whether the variation in excess returns across these portfolios reflects a compensation for risk, I conduct time series asset pricing tests using the CAPM, Carhart (1997) four factor model, and the Fama-French (2014) five factor model as the benchmark asset pricing models. Fama-French five-factor model augments the FamaFrench (1993) three-factor model by adding profitability (RMW) and investment (CMA) factors. As demonstrated in Table 1, my lease ratio is related to size at the firm level. Therefore, I explore whether the returns of lease-ratio-sorted portfolios are systematically related to the SMB factor.

Table 6 presents the alphas (pricing errors) and betas of lease-ratio-sorted portfolios for the CAPM, Carhart and Fama-French models. Alphas are estimated as intercepts from the regressions of lease ratio-sorted portfolio excess returns on the market excess return portfolio (MKT), SMB, HML, momentum (MOM), robust minus weak (RMW) and conservative minus aggressive (CMA) factors. RMW is the return spread of the portfolios of the most profitable firms minus the least profitable, and CMA is the return spread of the portfolios of firms that invest conservatively minus aggressively. Fama and French (2014) measure profitability by revenues minus the cost of goods sold, interest expense, and selling, general and administrative expenses, all divided by book equity and their measure of investment rate is the growth of total assets divided by total assets. The top panel of the table reports the results for equal-weighted portfolios, and the lower panel reports value-weighted portfolio results. I find that portfolios with high lease ratios load heavily on SMB, whereas the loadings of the low lease ratio portfolios are low, even negative in value-weighted portfolios. The loadings on HML, RMW and CMA are nonmonotonic. Value-weighted high lease ratio portfolios have higher loadings on MKT 


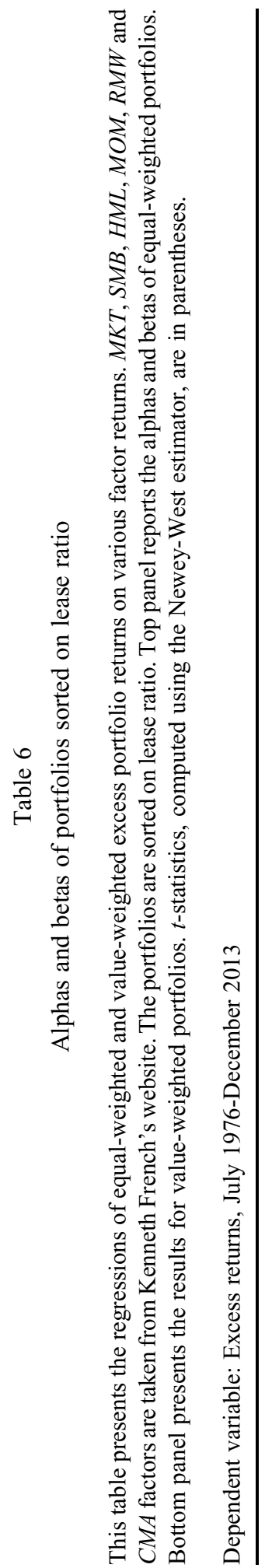

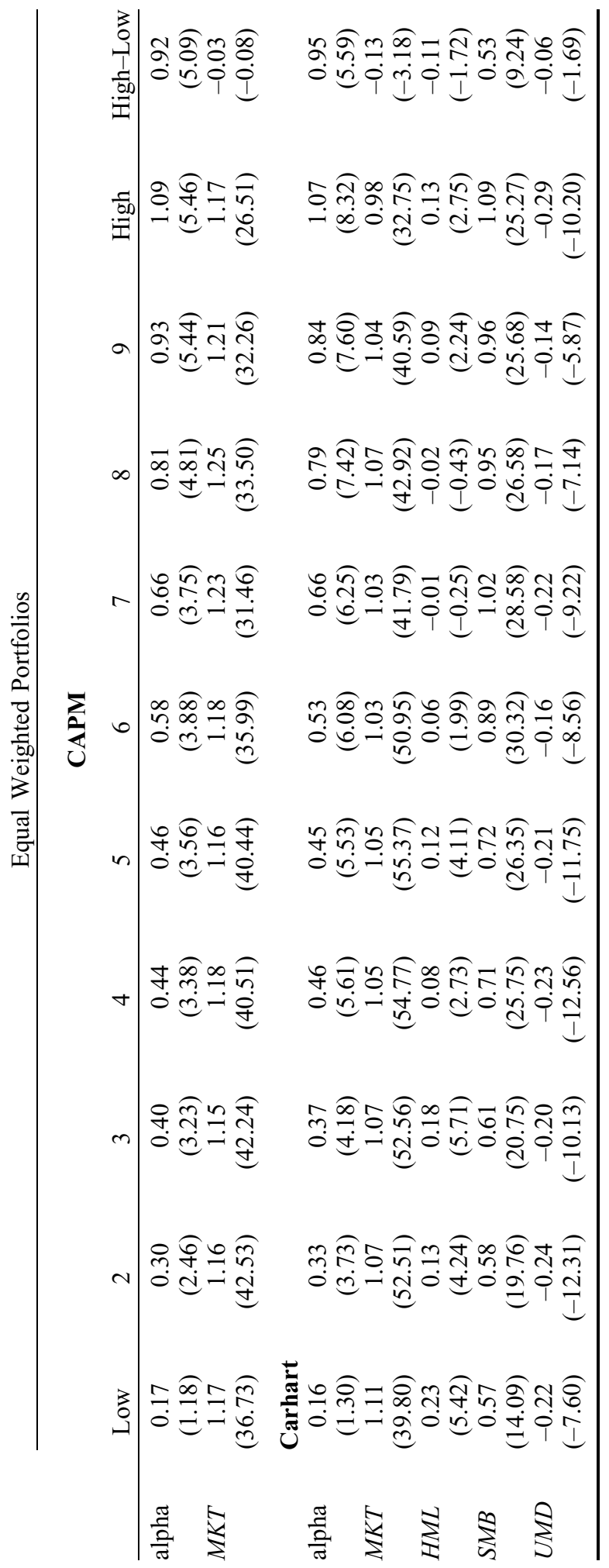




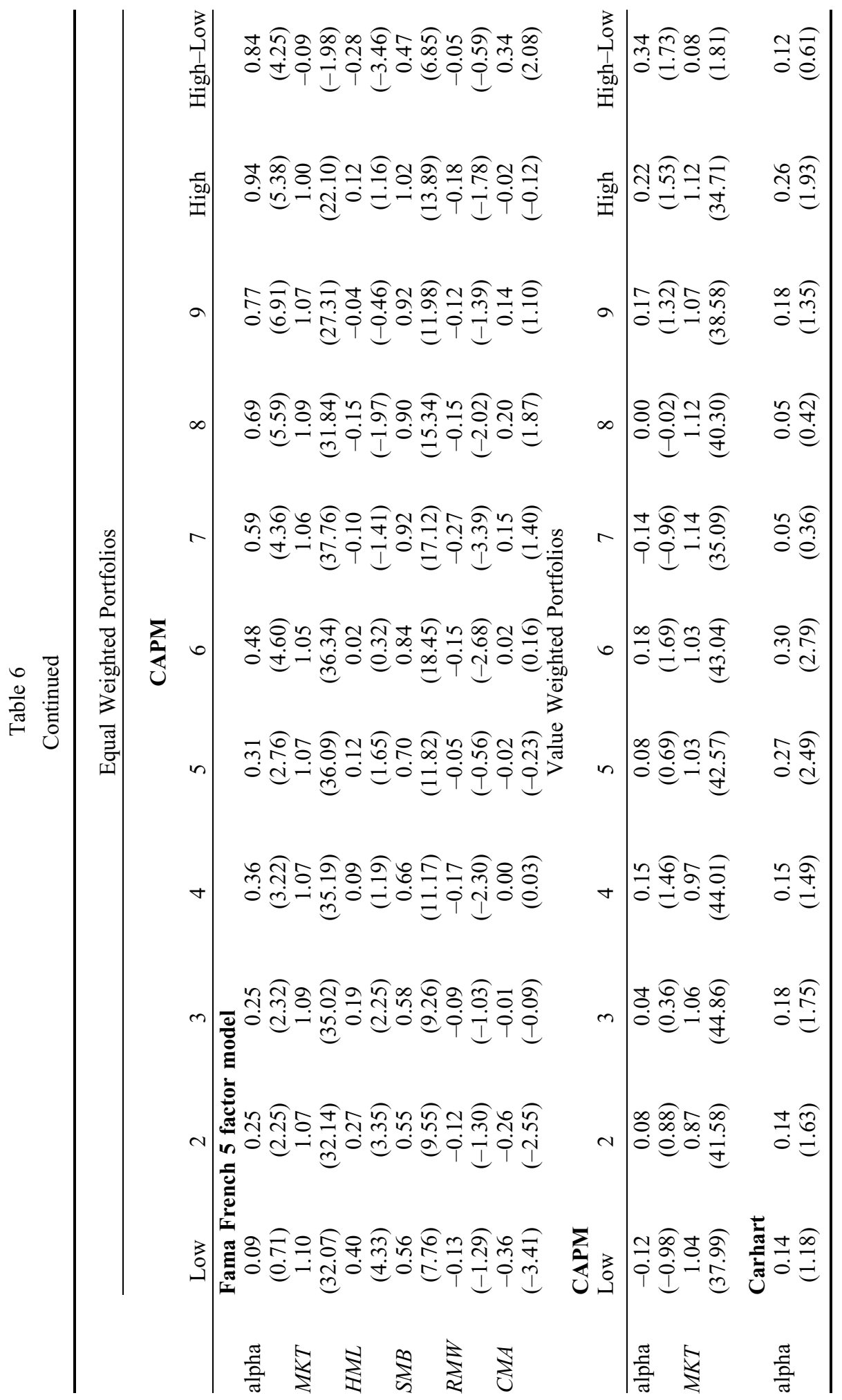




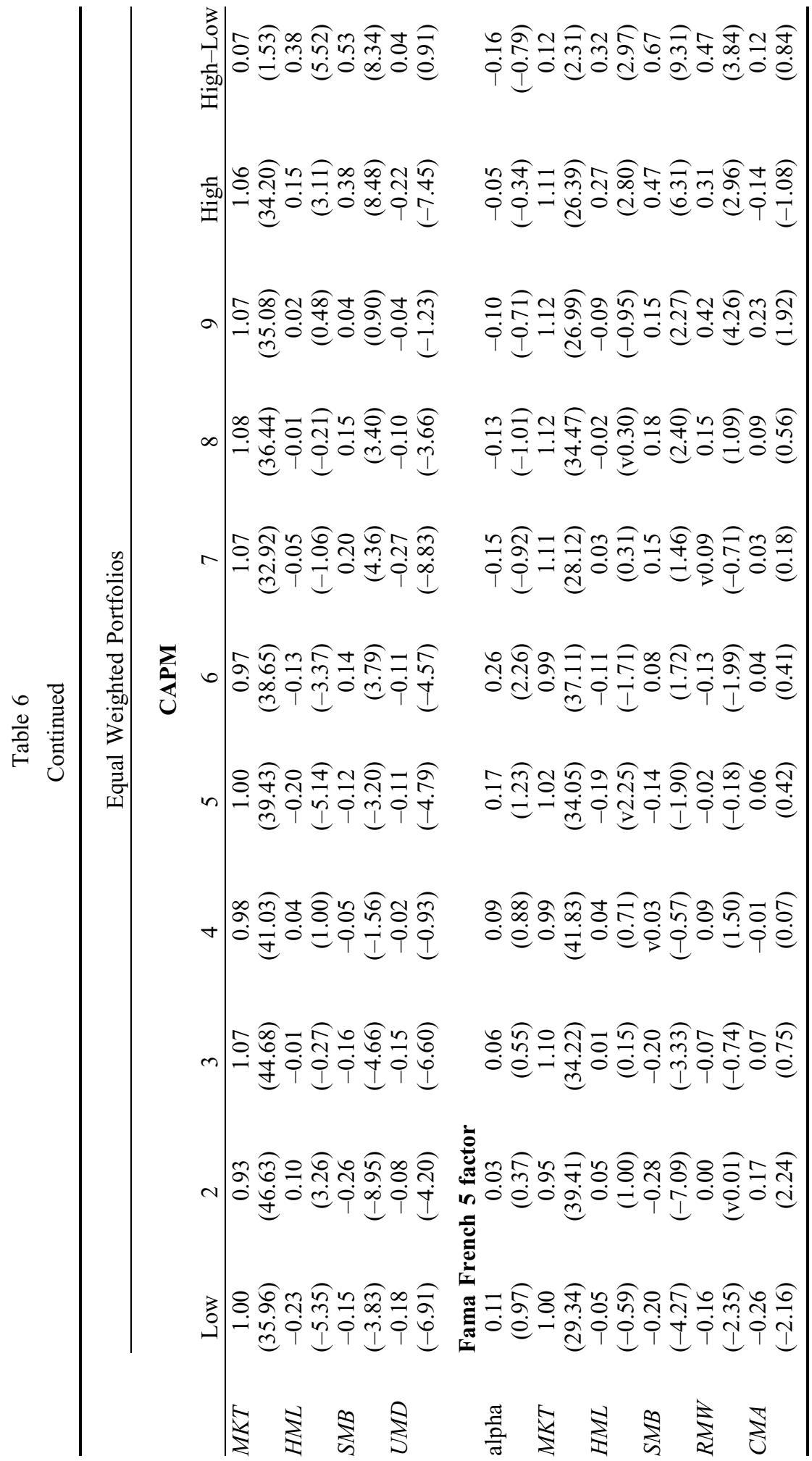


compared to low-lease ratio portfolios. Dropping the momentum factor has no material impact on these results.

None of the models completely explains the return spread in the equally weighted portfolios: The High-Low lease ratio portfolio has a CAPM alpha of 11.04\%, a Carhart alpha of $11.40 \%$, and Fama-French five factor alpha of $10.08 \%$, all statistically significant. The spreads in the alphas of the value-weighted portfolios are not statistically significant. Based on these results, I do not propose that the lease ratio is a separate risk factor that is not captured by these factors, but rather that the lease ratio is systematically related to SMB.

\subsection{Cost inflexibility}

Eventually all costs are variable in the long run. In the short run, it is hard to decide which costs are fixed, their degree of inflexibility and their duration of inflexibility (one month, one quarter or one year). As Novy-Marx (2011) explains, for operating leverage to significantly impact the riskiness of the firm requires both high levels of operating costs, and 'limited operational flexibility', which is the revenue beta minus cost beta. The level of fixed costs and the degree of operational inflexibility could be correlated across firms. Firms with high levels of inflexible costs could become more proficient in managing their fixed cost exposure. This leads to higher cost betas and high operational flexibility.

For example, one of the largest expense items, wage expense is sticky and acts as a fixed cost according to Hall (2005) and Favilukis and Lin (2013). At the same time, Tuzel and Zhang (2013) show that there are differences among firms in their flexibility to adjust wages in response to aggregate shocks. Firms located in cyclical areas can adjust wages better than firms located in less cyclical areas, leading to lower risk for the former. Labour is possibly a quasi-fixed cost and, since labour expense is not reported on firm income statements as a separate expense item but, rather, under the cost of goods sold and selling, general and administrative expenses, it is difficult to measure its degree of flexibility.

We know that non-cancellable lease commitments are non-cancellable except when the firm enters into Chapter 11 bankruptcy. Interest expense and pension and retirement expense are other potential inflexible operating costs to the firm and are reported separately in the financial statements. We have limited information on the ability of firms to manage their exposure to these costs. For example, firms enter into interest rate swaps and financial derivatives contracts to manage their interest rate risk related to fixed rate borrowings. In addition, interest rates fluctuate according to business cycles. Generally, in good times interest rates are high, and in bad times interest rates are low. Interest rates decreased over the 3 years during the financial crisis and firms benefited from this drop through lower interest expenses if the total borrowing remained the same. Table 7 shows that these other potential fixed costs - pension and retirement expense and interest expense - have a higher degree of operating flexibility than operating leases do.

First, I test the flexibility of costs using aggregate data, and then at the firm level. Fixed costs should have limited comovement with sales. For each year, I aggregate all the sales, non-cancellable lease commitments, interest expenses, and pension and retirement expenses for firms into aggregate-level variables. I calculate the growth rate of these series. Then, I regress different cost components on aggregate sales growth. Annual data are from 1976 to 2012 , with 37 observations. Table 7 reports the coefficients, $t$-statistics in parentheses, and $R^{2}$ values. Operating lease expense have a much smaller coefficient and $R^{2}$ values compared to other cost items. 
Table 7

Comovement of different costs with respect to sales at the market level

This table reports the results from regressions of different market (aggregate) cost growths on market sales growth. Each year, operating lease expense, interest expense, pension and retirement expense and sales are summed over all firms that year. Growth rate is calculated as the natural logarithm of the growth rate. Annual data are from 1976 to 2012 with 37 observations. Standard errors are Newey-West adjusted for three lags. Table reports the regression coefficients and $R^{2}$ values. $t$-statistics are in parentheses.

\begin{tabular}{lccc}
\hline & \multicolumn{3}{c}{ Dependent Variable } \\
\cline { 2 - 4 } & $\begin{array}{c}\text { Market Operating Lease } \\
\text { Expense Growth }\end{array}$ & $\begin{array}{c}\text { Market Interest } \\
\text { Expense Growth }\end{array}$ & $\begin{array}{c}\text { Market Pension \& Retirement } \\
\text { Expense Growth }\end{array}$ \\
\hline $\begin{array}{c}\text { Market Sales } \\
\text { Growth }\end{array}$ & $0.36(2.76)$ & $1.04(5.51)$ & $1.13(3.71)$ \\
$\mathrm{R}^{2}$ & $23.71 \%$ & $43.76 \%$ & $37.51 \%$ \\
\hline
\end{tabular}

Next, I follow Anderson et al. (2003) and investigate the sensitivities of these costs to increases and decreases in sales. I estimate the following regression:

$$
\begin{aligned}
& \log \left(\text { Cost }_{i, t} / \text { Cost }_{i, t-1}\right)= \\
& \quad \beta_{0}+\beta_{1} \log \left(\text { Sales }_{i, t} / \text { Sales }_{i, t-1}\right)+\beta_{2} *\left(\text { Dummy }_{i, t} * \log \left(\text { Sales }_{i, t} / \text { Sales }_{i, t}\right)\right)+{ }_{\varepsilon i, t} .
\end{aligned}
$$

where Cost is either a non-cancellable lease commitment, interest expense, or pension and retirement expense for firm $i$. Dummy, takes the value of one when sales decreases between years $t-1$ and $t$, and zero otherwise. The coefficient $\beta_{1}$ measures the percentage increase in costs with a $1 \%$ increase in sales. Because the value of Dummy is one when sales decreases, the sum of the coefficients, $\beta_{1}+\beta_{2}$, measures the percentage decrease in costs with a $1 \%$ decrease in sales. Table 8 reports the coefficients, the $t$-statistics in parentheses and $R^{2}$ values from the pooled ordinary least squares regression. The $\beta_{1}$ coefficient of operating leases is smaller than for other costs and $\beta_{1}+\beta_{2}$ is close to zero, meaning that a $1 \%$ decline in sales results in a $0.02 \%$ increase in operating lease expenses. Although interest and pension expenses are sticky, the combined measure of inflexibility has a higher $\beta_{1}+\beta_{2}$ coefficient, 0.13 , than operating lease expenses alone, -0.02 .

These results jointly indicate that among these costs, a non-cancellable operating lease expense behaves as a fixed cost and has less comovement with sales than other costs do. Therefore, operating lease commitments are a source of operating leverage risk to the firm.

\subsection{Unlevered equity returns}

I also consider whether the impact of the lease ratio is related to financial leverage. In Table 1, high lease ratio firms have lower financial leverage. This negative relation could imply that leasing and debt are substitutes, or that managers offset the risk of lease commitments on equity through lower financial leverage. In the Fama-MacBeth 
Table 8

Comovement of different costs with respect to sales at the firm level

This table reports the results from regressions of different cost growths on sales growth. The ratios are winsorised at the top and bottom $0.5 \%$ to decrease the influence of outliers. Only firms with non-missing non-cancellable lease commitment, interest expense, pension and retirement expense growth rates are included in the regressions to be able to compare the regression coefficients. The table reports the regression coefficients and $R^{2}$ values. $t$-statistics are in parentheses.

\begin{tabular}{lccc}
\hline & $\begin{array}{c}\text { Operating Lease } \\
\text { Expense Growth }\end{array}$ & $\begin{array}{c}\text { Interest Expense } \\
\text { Growth }\end{array}$ & $\begin{array}{c}\text { Pension Expense } \\
\text { Growth }\end{array}$ \\
\hline$\beta_{1}$ & $0.46(42.26)$ & $0.88(44.00)$ & $0.64(42.43)$ \\
$\beta_{2}$ & $-0.48(-16.87)$ & $-0.48(-9.30)$ & $-0.19(-4.86)$ \\
$\beta_{1}+\beta_{2}$ & -0.02 & 0.39 & 0.45 \\
$\mathrm{R}^{2}$ & $6 \%$ & $9 \%$ & $10 \%$ \\
\hline
\end{tabular}

regressions, financial leverage has no impact on the marginal power of the lease ratio. However, I cross-check my results using portfolio sorts with unlevered excess returns. For each firm, I compute the unlevered cost of equity from the standard weighted average cost of capital formula, as follows:

$$
R_{i, m, t}^{U}=\left[R_{i, m, t}\left(1-L_{i, t-1}\right)+R_{i, m, t}^{B} L_{i, t-1}\left(1-\rho_{t-1}\right)\right]-R_{m, t}^{T}
$$

where $R_{i, m, t}$ denotes the monthly stock return of firm $i$ over month $m$ of year $t, R_{m, t}^{T}$ denotes the 1-month Treasury bill rate in month $m$ of year $t, R_{i, m, t}^{B}$ denotes the monthly debt return of firm $i$ over month $m$ of year $t$, and $L_{i, t-1}$ denotes the leverage ratio, defined as the book value of debt over the sum of the book value of debt plus the market value of equity at the end of year $t-1 . \rho_{t-1}$ is the firm's tax rate.

Firm-level corporate bond data are limited, and only a small percentage of firms have corporate bond ratings in Compustat (item SPLTICRM). To construct bond returns, $R_{i, m, t}^{B}$, for firms without bond ratings, I follow Liu et al. (2009). The computation involves imputing bond ratings for all firms in my sample following the procedure of Blume et al. (1998). To impute bond ratings, I first estimate an ordered probit model that relates credit ratings to observed explanatory variables using all firms that have credit ratings. Second, from this regression, I calculate the cut-off values for each rating. Third, I estimate the credit scores for firms without credit ratings using the coefficients estimated from the ordered probit model and impute bond ratings by applying the cut-off values for the different credit ratings. Finally, I match the corresponding corporate bond returns to a given credit rating for all firms with the same credit rating. The bond return data are from Barclays Capital US Long Term Corporate Bond Returns for the Aaa, Aa, A, Baa and high yield rating categories. The data source is Morningstar.

The ordered probit model contains the following explanatory variables: interest coverage ${ }^{17}$ ratio of operating income after depreciation (item OIADP) plus interest

\footnotetext{
${ }^{17}$ Interest coverage ratios of less than zero are replaced by zero and any interest coverage ratio greater than 10 is set to 104 , as in Blume et al. (1998).
} 
expense (item XINT) to interest expense; operating margin, ratio of operating income before depreciation (item OIBDP) to sales (item SALE), long-term leverage, ratio of long-term debt (item DLTT) to assets (item AT); total leverage, ratio of long-term debt plus debt in current liabilities (item DLC) plus short-term borrowing (item BAST) to assets; natural logarithm of the market value of equity (item PRCC_C times item CSHO) deflated to 1973 by the consumer price index; and market beta (CRSP data item BETAV) and standard deviation of returns (CRSP data item SDEVV). Data on rating categories are available from January 1973 onward. I measure $\rho_{t-1}$ as the statutory corporate income tax rate. From 1973 to 1978 , the tax rate was 48\%, dropping to $46 \%$ in 1986 , and then to $40 \%$ in 1987, and further to $34 \%$ in 1987 and then staying at that level thereafter. The data source is the Commerce Clearing House, annual publications.

I repeat the portfolio sorts using unlevered expected excess returns as the cost of capital measure. Table 9 presents the equal- and value-weighted expected excess unlevered returns of decile portfolios sorted by lease ratio. In equal-weighted and valueweighted returns, the spreads are slightly smaller, but still significant.

\subsection{Industry adjusted lease ratio}

The capital composition of firms can vary across industries. For example, airlines and retail industries are known to be heavy users of operating leases. To compare firms from different industries, I calculate industry-adjusted lease ratios for firms. Every year, I form industry portfolios using two-digit SIC codes and calculate the average lease ratio within each portfolio. Then I subtract the corresponding industry's average lease ratio from the firm's lease ratio. The industry adjusted lease ratios of firms are the lease ratios in excess of their industry averages. In June of each year, I rank stocks according to this industryadjusted lease ratio and group them into decile portfolios. There must be at least five firms each year from each two digit SIC code to include firms from that industry. Following Fama and French (1993), I match the CRSP stock return data from July of year $t+1$ to June of year $t+2$ with the industry-adjusted lease ratio for the fiscal year ending in year $t$. Table 10 presents the excess returns and unlevered returns of industry-adjusted lease ratio-sorted portfolios. The results show that the spread is higher (lower) in valueweighted (equal-weighted) portfolios sorted with industry adjustment compared to the portfolios formed without industry adjustment.

As in Novy-Marx (2011), I decompose the operating lease ratio into industry and intraindustry components using two different methodologies. The first method uses the operating lease ratio demeaned by the industry average as the intra-industry operating lease ratio. This industry adjusted lease ratio generates significant spread in returns as shown in Table 10. The industry average lease ratio is the component of the lease ratio related to industry variation. The second method uses the firm's operating lease ratio ranking within its industry as the intra-industry measure and the ranking of the operating lease ratio of the firm's industry as the industry measure. These rankings are percentiles parameterised between zero and one.

Table 11 shows the results from Fama-MacBeth regressions employing measures of the operating lease ratio within and across industries. Under both decomposition methods, the intra-industry measure has significantly more power than the industry measure. The coefficients of the intra-industry measure are large and highly significant, while the coefficients of the industry measure are smaller and insignificant. These results further confirm that the operating lease operating leverage effect is independent of 


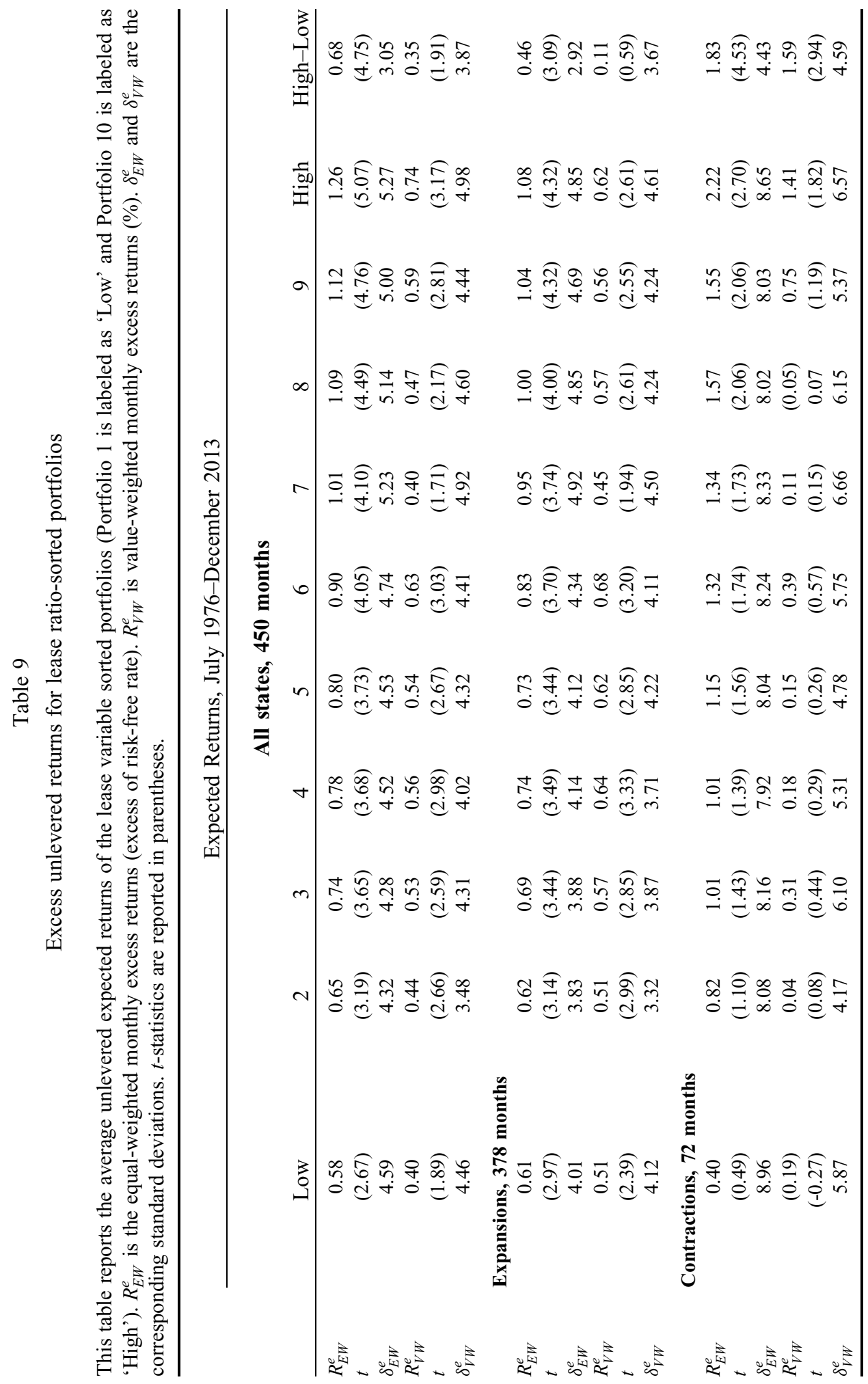




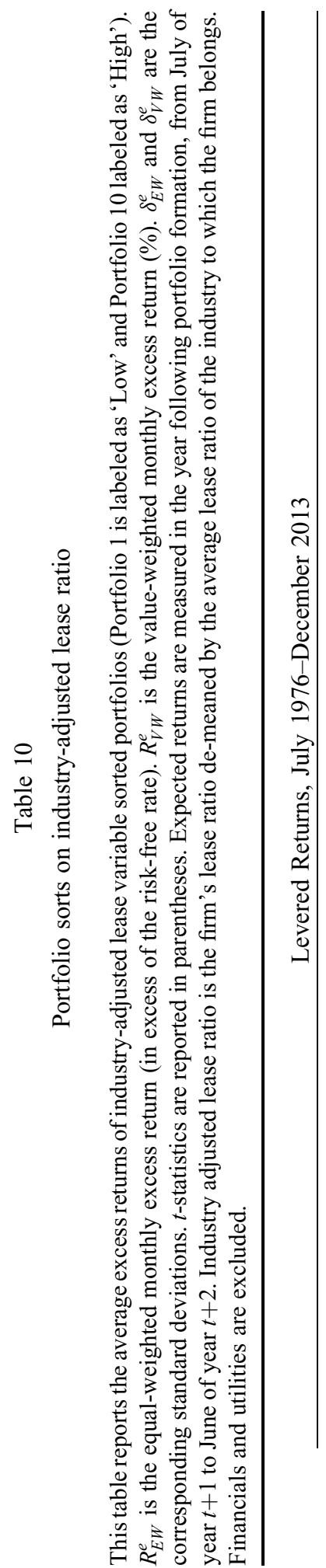

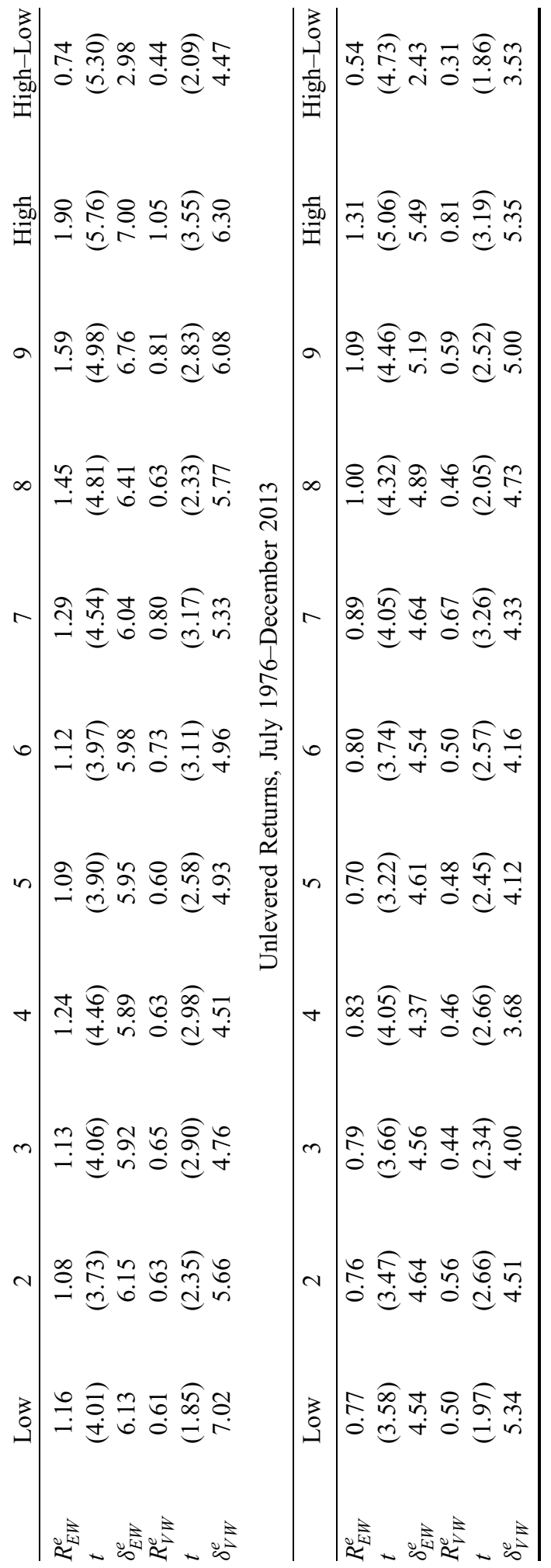




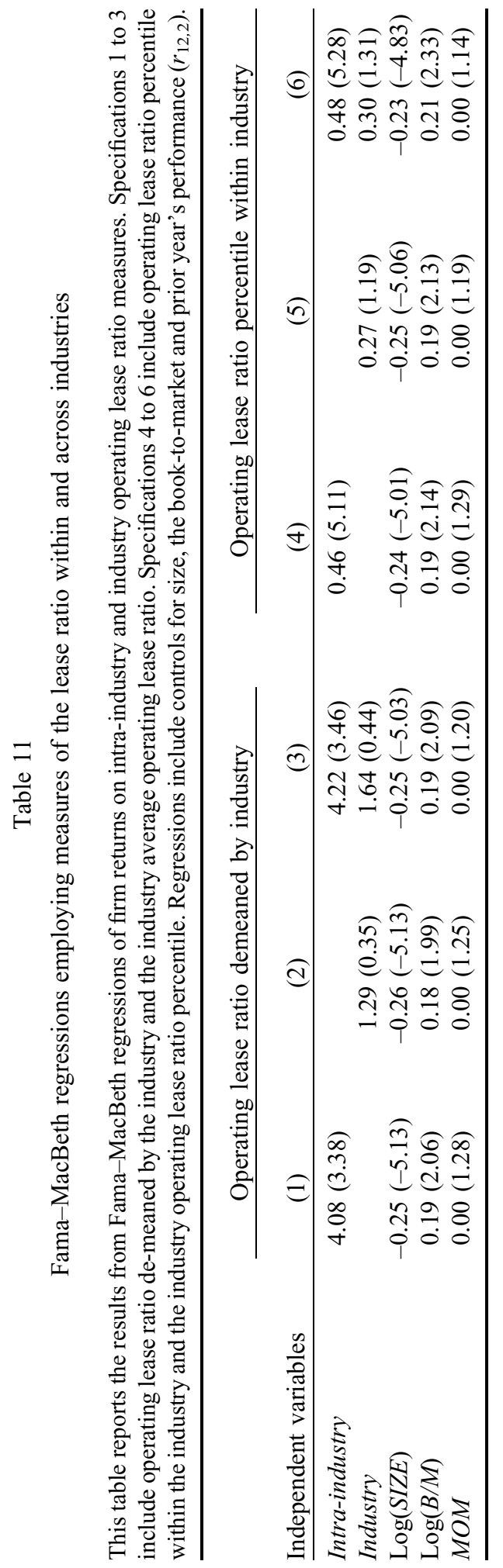


industry effects. The impact of operating leases on the risk and returns of the firm is more pronounced within industries than across industries.

\subsection{Cash flow sensitivity}

I investigate further whether there are systematic differences in the sensitivity of high and low lease ratio firm cash flows to aggregate shocks in the economy. Such a difference could support the operating leverage mechanism behind the risk and return differences between high- and low-lease ratio firms. I expect that the cash flows of firms with high lease ratios would be more sensitive to aggregate shocks than the cash flows of low-lease ratio firms. The measure for cash flow is firm income before extraordinary items plus depreciation. I estimate the following pooled time series/cross-sectional regressions:

$$
\Delta \text { CashFlow }_{i, t}=\propto_{i}+\beta \Delta \text { CashFlow }_{\text {agg }, t}+u_{i, t}
$$

where $\Delta$ CashFlow $_{i, t}$ is the change in cash flows of firm $i$ between year $t-1$ and $t$, scaled by firm assets in year $t-1$. The term $\propto_{i}$ captures the individual firm effect and I proxy for

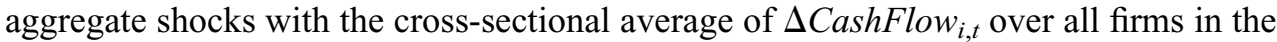
sample. Since I use $\Delta$ CashFlow on each side of the regression, at the firm level on the left hand side and aggregate on the right hand side, I can interpret the regression coefficient as the firm's cash flow beta to aggregate shocks. I divide firms into 10 lease ratio deciles based on their lease ratio in year $t-1$, and I run panel regressions in each lease ratio decile and present the regression coefficients in Table 12. High-lease ratio firms have greater sensitivity to aggregate shocks in the economy. The regression coefficients are 1.45 for firms in the highest lease ratio group and 0.27 for the lowest lease ratio group. Firms' cash flow betas increase monotonically with their operating lease ratios.

The link between firm sensitivity to existing sources of risk and the firm's operating leverage implies that volatility should increase with operating leverage. I show that the

\section{Table 12}

Cash flow regressions for lease ratio-sorted panels

The top panel in this table presents the results of panel regressions of changes in firm-level cash flow on changes in aggregate cash flow. Changes in cash flow are measured as the level difference between cash flows at time $t$ and $t-1$, scaled by total assets at time $t-1$. Changes in aggregate cash flow are measured as the cross-sectional average of firm-level changes. Firms are sorted into 10 decile groups based on the past year's lease ratios. The sample period is from 1975 to 2012. Firm fixed effects are included. Standard errors are clustered by firm. $t$-statistics are in parentheses. The bottom panel presents the standard deviation of the average cash flow growth of the lease ratio-sorted decile portfolios.

Dependent Variable: $\Delta$ CashFlow $_{\mathrm{i}, \mathrm{t}}$

\begin{tabular}{ccccccccccc} 
& Low & 2 & 3 & 4 & 5 & 6 & 7 & 8 & 9 & High \\
\hline CashFlow $_{\text {agg,t }}$ & 0.27 & 0.40 & 0.47 & 0.69 & 0.54 & 0.70 & 0.69 & 0.69 & 1.06 & 1.45 \\
& $(2.07)$ & $(3.80)$ & $(3.42)$ & $(4.02)$ & $(3.44)$ & $(4.27)$ & $(3.79)$ & $(4.16)$ & $(3.67)$ & $(6.75)$
\end{tabular}

Volatility of cash flow growth

\begin{tabular}{ccccccccccc} 
& Low & 2 & 3 & 4 & 5 & 6 & 7 & 8 & 9 & High \\
\hline$\delta^{\mathrm{CF}}$ & $2.1 \%$ & $1.9 \%$ & $1.9 \%$ & $2.1 \%$ & $1.5 \%$ & $1.8 \%$ & $2.3 \%$ & $2.8 \%$ & $3.2 \%$ & $4.7 \%$ \\
\hline
\end{tabular}




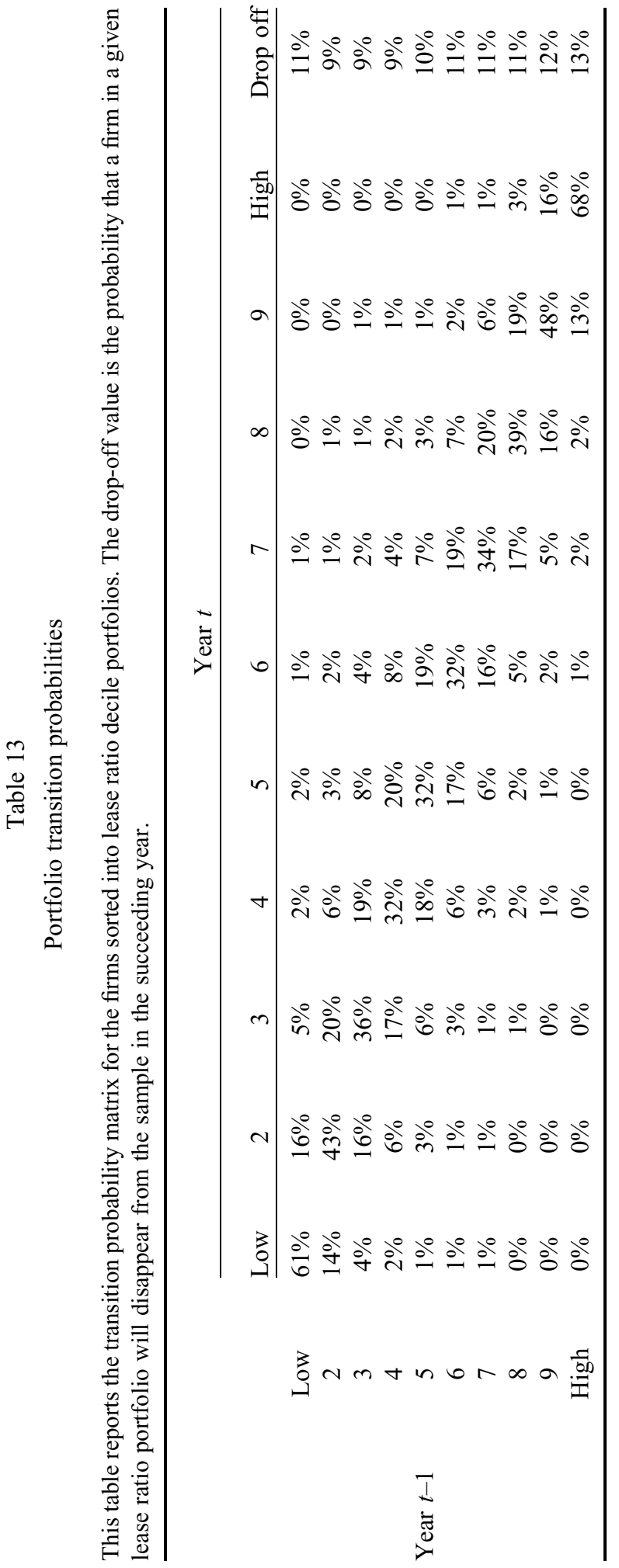




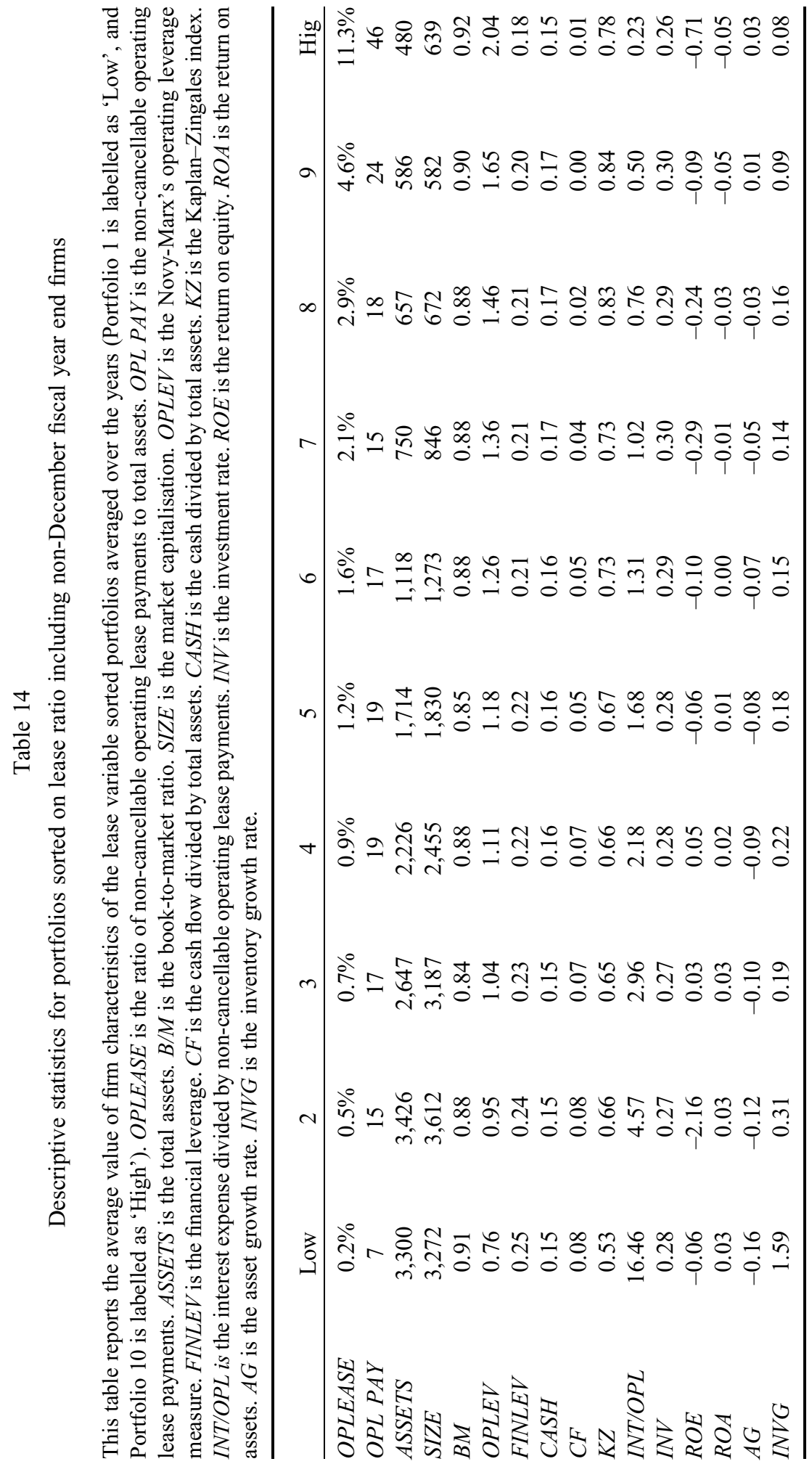




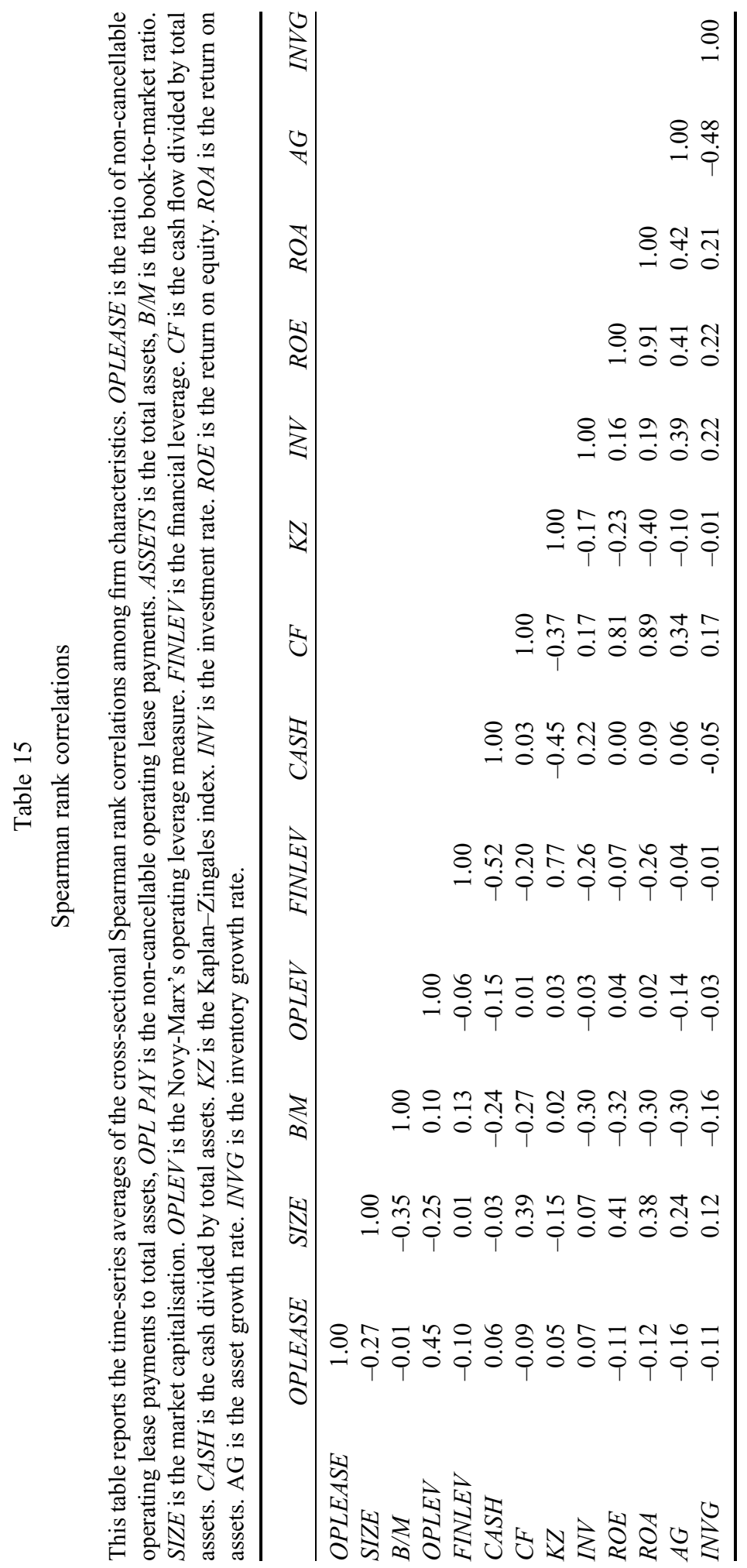




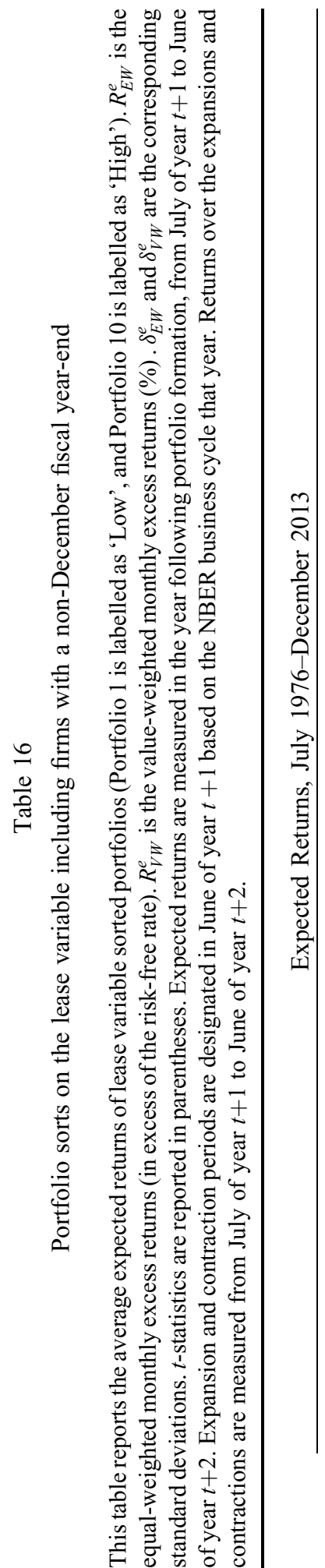

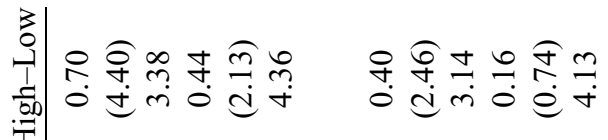

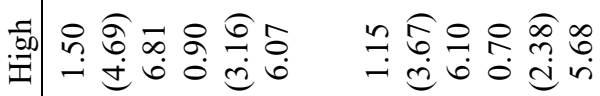

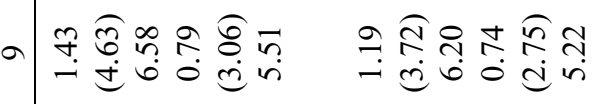

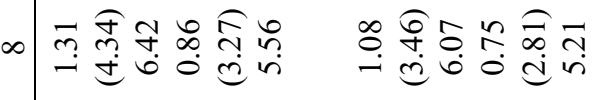

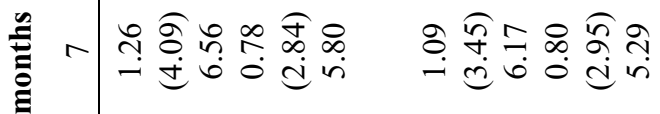

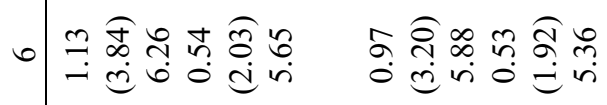

₹

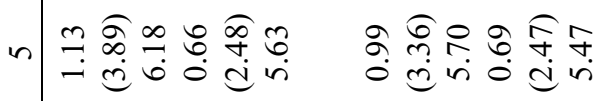

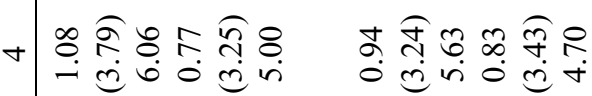

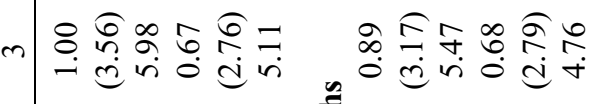

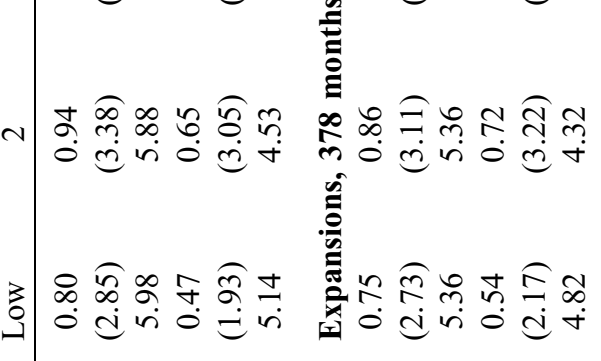

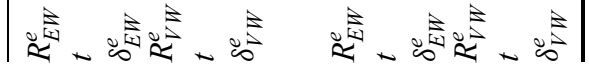




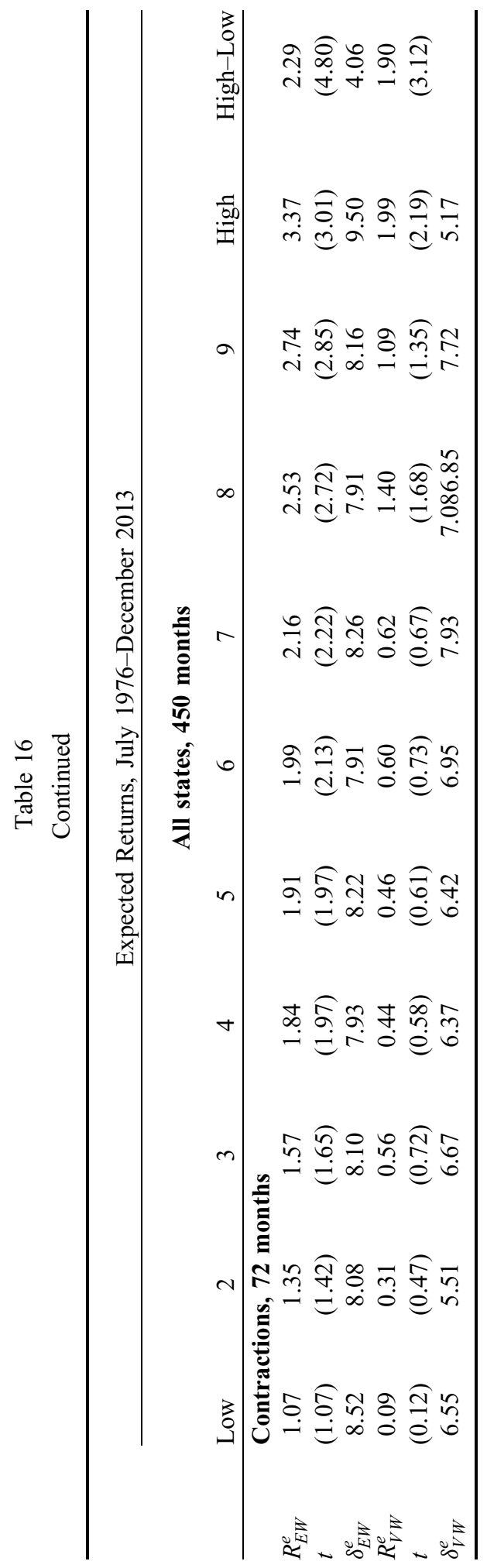


firm's cash flow sensitivity to aggregate shocks is increasing with operating leaseinduced operating leverage. At the same time, firms with high lease ratios have greater cash flow growth volatility. The bottom panel of Table 12 reports the decile portfolios' standard deviations in annual average cash flow growth. Table 3 also shows that those firms with high levels of operating leases have more volatile returns. Except for the first decile, the standard deviations of portfolio returns increase with the lease ratio. Tuzel (2010) supports this finding; firms with high levels of operating leases have much more volatile returns than firms that do not have a significant amount of operating leases.

\subsection{Persistency of the lease ratio}

I am also interested in whether the level of operating leases is a firm characteristic that shows persistence in the short run. I expect that the firm's fraction of leased capital changes over time depending on the firm's lifecycle. However, the probability of a firm moving from a particular decile to other deciles in the succeeding year should not be high since leased capital is difficult to adjust in the short run. Following Imrohoroglu and Tuzel (2014), Table 13 presents the transition probability matrix for the firms in the study's sample sorted into lease ratio decile portfolios. The probability of staying in the lowest lease ratio portfolio is $61 \%$, whereas the probability of staying in the highest lease ratio portfolio is $68 \%$. The higher probabilities along the diagonal show some persistency in the ratio of operating leases. The drop-off probabilities in Table 13 shows the probability that a firm in a given lease ratio portfolio will disappear from the sample in the succeeding year. The reasons for drop-off can be either firm failure or a missing data item in the succeeding year. The probability of drop-off is higher for firms in the highest lease ratio portfolio. Except for the first decile, the drop-off rate increases monotonically. Therefore, I interpret the higher drop-off rates of high-lease ratio firms as indicating a higher probability of failure.

\subsection{December fiscal year end requirement}

In the calculation of expected returns, CRSP stock return data from July of year $t+1$ to June of year $t+2$ is matched with accounting information for the fiscal year ending in year $t$, as in Fama and French $(1992,1993)$. This 6-month gap between the accounting information and returns guarantees that the accounting information is already impounded into the stock prices. To ensure that the accounting data are not outdated by the time of the sorting procedure, my sample includes only firms with a fiscal year ending in December. However, the results are very similar if I drop this December fiscal year-end restriction. Tables 14 to 16 reproduce the main results (Tables 1 and 2 for descriptive statistics and Table 3 for excess returns) based on the entire cross-section of firms that report their $M R C 1$ in the Compustat/CRSP merged database. The annual return spread for the equal-weighted portfolios is $8.4 \%$ and the corresponding spread for the value-weighted portfolios is $5.2 \%$.

\section{Conclusion}

This paper provides empirical evidence about the link between a firm's level of noncancellable operating lease commitments and expected stock returns, offering an economic explanation as to how firm characteristics can predict returns. The 
interpretation of the return differences of the lease ratio portfolios is that firms that have higher levels of operating leases also have higher operating leverage, and consequently are riskier than firms with lower levels of operating leases. Such firms with high levels of non-cancellable operating leases are particularly risky in recessionary periods.

There are several dimensions of operating leases that my simple lease ratio ignores here. For example, the nature of the lease contract, the maturity structure and restrictions on how the asset can be deployed or utilised (Tuzel, 2010) could affect the flexibility of the lease commitments. Currently, the FASB and IASB are working on a converged accounting standard for firms' leasing activities. When these regulatory bodies implement the new accounting rule on leases, future work in this area will provide a better picture of a firm's operating lease activities in the financial statements.

\section{References}

Anderson, M. C., Banker, R. D. and Janakiraman, S. N., 'Are selling, general, and administrative costs 'sticky'?' Journal of Accounting Research, Vol. 41 (1), 2003, pp. 47-63.

Ang, J. and Peterson, P. P., 'The leasing puzzle', Journal of Finance, Vol. 39 (4), 1984, pp. 1055-65.

Belo, F., Lin, X. and Bazdresch, S., 'Labor hiring, investment, and stock return predictability in the cross section', Journal of Political Economy, Vol. 122 (1), 2014, pp. 129-77.

Blouin, J., Core, J. E. and Guay, W., 'Have the tax benefits of debt been overestimated?' Journal of Financial Economics, Vol. 98 (2), 2010, pp. 195-213.

Blume, M. E., Lim F. and MacKinlay A.C., 'The declining credit quality of US corporate debt: Myth or reality?' Journal of Finance, Vol. 53 (4), 1998, pp. 1389-413.

Carhart, M. M., 'On persistence in mutual fund performance', Journal of Finance, Vol. 52 (1), 1997, pp. $57-82$.

Carlson, M., Fisher, A. and Giammarino, R., 'Corporate investment and asset price dynamics: Implications for the cross section of returns', Journal of Finance, Vol. 59 (6), 2004, pp. 2577-603.

Chen, C. X., Lu, H. and Sougiannis, T., 'The agency problem, corporate governance, and the asymmetrical behavior of selling, general, and administrative costs', Contemporary Accounting Research, Vol. 29 (1), 2012, pp. 252-82.

Chen, H. J., Kacperczyk, M. and Ortiz-Molina, H., 'Labor unions, operating flexibility, and the cost of equity', Journal of Financial and Quantitative Analysis, Vol. 46 (1), 2011, pp. 25-58.

Chen, Z., Harford J. and Kamara A., 'Operating inflexibility, profitability and capital structure', Working paper University of Reading and University of Washington, 2014.

Cochrane, J., 'Production-based asset pricing and the link between stock returns and economic fluctuations', Journal of Finance, Vol. 46 (1), 1991, pp. 209-37.

Cooper, M., Gulen H. and Schill M.J., 'Asset growth and the cross-section of stock returns', Journal of Finance, Vol. 63 (4), 2008, pp. 1609-651.

Cornaggia, K. J., Franzen, L. A. and Simin, T. T., 'Bringing leased assets onto the balance sheet', Journal of Corporate Finance, Vol. 22, 2013, pp. 345-60.

Cosci, S., Guida, R. and Meliciani, V., 'Leasing decisions and credit constraints: Empirical analysis on a sample of Italian firms', European Financial Management, Vol. 21 (2), 2013, 377-98

Danthine, J., and Donaldson, J. B., 'Labor relations and asset returns', Review of Economic Studies, Vol. 69 (1), 2002, pp. 41-64.

Dhaliwal, D., Lee, H. S. G. and Neamtiu, M., 'The impact of operating leases on firm financial and operating risk', Journal of Accounting, Auditing and Finance, Vol. 26 (2), 2011, pp. 151-197.

Donangelo, A., 'Labor mobility: Implications for asset pricing', Journal of Finance, Vol. 69 (3), 2014, pp. 1321-346.

Easley, D., Hvidkjær S. and O'Hara M., 'Is information risk a determinant of asset returns?' Journal of Finance, Vol. 57 (5), 2002, pp. 2185-221. 
Eisfeldt, A. L. and Rampini A.A. 'Leasing, ability to repossess, and debt capacity', Review of Financial Studies, Vol. 22 (4), 2009, pp. 1621-657.

Ely, K. M., 'Operating lease accounting and the market's assessment of equity risk', Journal of Accounting Research, Vol. 33 (2), 1995, pp. 397-415.

Fama, E. F. and French, K. R., 'The cross-section of expected stock returns', Journal of Finance, Vol. 47 (2), 1992, pp. 427-66.

Fama, E. F. and French, K. R., 'Common risk factors in the returns on stocks and bonds', Journal of Financial Economics, Vol. 33 (1), 1993, pp. 3-56.

Fama, E. F. and French, K. R., 'Dissecting anomalies', Journal of Finance, Vol. 63 (4), 2008, pp. $1653-78$.

Fama, E. F. and French, K. R., 'A five-factor asset pricing model', Working paper, University of Chicago, Dartmouth College and the National Bureau of Economic Research, 2014.

Fama, E. F. and MacBeth, J. D., 'Risk, return, and equilibrium: Empirical tests', Journal of Political Economy, Vol. 81 (3), 1973, pp. 607-36.

Favilukis J. and Lin, X., 'Does wage rigidity make firms riskier? Evidence from long-horizon return predictability', Working paper, London School of Economics and Ohio State University, 2013.

Gomes, J. F. and Schmid, L., 'Levered returns', Journal of Finance, Vol. 65 (2), 2010, pp. 467-94.

Gourio, F., 'Labor leverage, firm's heterogeneous sensitivities to the business cycle, and the crosssection of returns', Working paper, Boston University, 2007.

Graham, J. R., Lemmon, M. L. and Schallheim, J. S., 'Debt, leases, taxes, and the endogeneity of corporate tax status', Journal of Finance, Vol. 53 (1), 1998, pp. 131-62.

Hadlock, C. J. and Pierce, J. R., 'New evidence on measuring financial constraints: Moving beyond the KZ index', Review of Financial Studies, Vol. 23 (5), 2010, pp. 1909-40.

Hall, R., 'Employment fluctuations with equilibrium wage stickiness', American Economic Review, Vol. 95 (1), 2005, pp. 50-65.

Imhoff, E. A., Lipe, R. C. and Wright, D.W., 'The effects of recognition versus disclosure on shareholder risk and executive compensation', Journal of Accounting Auditing and Finance, Vol. 8 (4), 1993, pp. 335-68.

Imrohoroglu, A. and Tuzel, S., 'Firm level productivity, risk, and return', Management Science, Vol. 60 (8), 2014, pp. 2073-90.

Kaplan, S. N. and Zingales, L., 'Do investment-cash flow sensitivities provide useful measures of financial constraints?' Quarterly Journal of Economics, Vol. 112 (1), 1997, pp. 159-216.

Lamont, O., Polk, C. and Saa-Requejo, J., 'Financial constraints and stock returns', Review of Financial Studies, Vol. 14 (2), 2001, pp. 529-54.

Lasfer, M. A. and Levis, M., 'The determinants of the leasing decision of small and large companies', European Financial Management, Vol. 4 (2), 1998, pp. 159-84.

Lev, B., 'On the association between operating leverage and risk', Journal of Financial and Quantitative Analysis, Vol. 9 (04), 1974, pp. 627-41.

Lewis, C. M. and Schallheim, J. S., 'Are debt and leases substitutes?' Journal of Financial and Quantitative Analysis, Vol. 27 (04), 1992, pp. 497-511.

Lim, C. S., Mann, C. S. and Mihov T.V., 'Market evaluation of off-balance sheet financing: You can run but you can't hide', Working paper, Texas Christian University, 2005.

Liu, L. X., Whited T. M. and Zhang L., 'Investment-based expected stock returns', Journal of Political Economy, Vol. 117 (6), 2009, pp. 1105-139.

Mandelker, G.N., and Rhee S.G., 'The impact of the degrees of operating and financial leverage on systematic risk of common stock', Journal of Financial and Quantitative Analysis, Vol. 19 (01), 1984, pp. 45-57.

Newey, W. and West, K., 'A simple, positive semi-definite, heteroskedasticity and autocorrelation consistent covariance matrix', Econometrica, Vol. 55 (3), 1987, pp. 703-708.

Novy-Marx, R., 'Operating leverage', Review of Finance, Vol. 15 (1), 2011, pp. 103-34.

Rubinstein, M. E., 'A mean-variance synthesis of corporate financial theory', Journal of Finance, Vol. 28 (1), 1973, pp. 167-82. 
Sharpe, A. S. and Nguyen, H. H., 'Capital market imperfections and the incentive to lease', Journal of Financial Economics, Vol. 39 (2), 1995, pp. 271-94.

Titman, S., Wei, K. and Xie, F., 'Capital investment and stock returns', Journal of Financial and Quantitative Analysis, Vol. 39 (04), 2004, pp. 677-700.

Tuzel, S., 'Corporate real estate holdings and the cross section of stock returns', Review of Financial Studies, Vol. 23 (6), 2010, pp. 2268 - 302.

Tuzel, S. and Zhang, M. B., 'Local risk, local factors, and asset prices', Working paper, University of Southern California and University of Texas at Austin, 2013.

Whited, T. M. and Wu, G., 'Financial constraints risk', Review of Financial Studies, Vol. 19 (2), 2006, pp. 531-59. 